\title{
Anthropogenic and natural methane fluxes in Switzerland synthesized within a spatially explicit inventory
}

\author{
R. V. Hiller ${ }^{1,2}$, D. Bretscher ${ }^{3}$, T. DelSontro ${ }^{4,5}$, T. Diem ${ }^{4}$, W. Eugster ${ }^{6}$, R. Henneberger ${ }^{5}$, S. Hobi ${ }^{7}$, E. Hodson ${ }^{7}$, \\ D. Imer ${ }^{6}$, M. Kreuzer ${ }^{6}$, T. Künzle ${ }^{8}$, L. Merbold ${ }^{6}$, P. A. Niklaus ${ }^{9}$, B. Rihm ${ }^{8}$, A. Schellenberger ${ }^{10}$, M. H. Schroth ${ }^{5}$, \\ C. J. Schubert ${ }^{4}$, H. Siegrist ${ }^{11}$, J. Stieger ${ }^{6}$, N. Buchmann ${ }^{6}$, and D. Brunner ${ }^{1}$ \\ ${ }^{1}$ Empa, Swiss Federal Laboratories for Materials Science and Technology, Duebendorf, Switzerland \\ ${ }^{2}$ Federal Office of Meteorology and Climatology MeteoSwiss, Zurich, Switzerland \\ ${ }^{3}$ Agroscope, Institute for Sustainability Sciences, Zurich, Switzerland \\ ${ }^{4}$ Eawag, Swiss Federal Institute of Aquatic Science and Technology, Kastanienbaum, Switzerland \\ ${ }^{5}$ ETH Zurich, Institute for Biogeochemistry and Pollutant Dynamics, Zurich, Switzerland \\ ${ }^{6}$ ETH Zurich, Institute of Agricultural Sciences, Zurich, Switzerland \\ ${ }^{7}$ WSL, Swiss Federal Institute for Forest, Snow and Landscape Research, Birmensdorf, Switzerland \\ ${ }^{8}$ Meteotest, Bern, Switzerland \\ ${ }^{9}$ University of Zurich, Institute of Evolutionary Biology and Environmental Studies, Zurich, Switzerland \\ ${ }^{10}$ FOEN, Federal Office for the Environment, Bern, Switzerland \\ ${ }^{11}$ Eawag, Swiss Federal Institute of Aquatic Science and Technology, Duebendorf, Switzerland
}

Correspondence to: R. V. Hiller (hillerrv@gmail.com)

Received: 13 August 2013 - Published in Biogeosciences Discuss.: 17 September 2013

Revised: 2 February 2014 - Accepted: 11 February 2014 - Published: 9 April 2014

\begin{abstract}
We present the first high-resolution $(500 \mathrm{~m} \times$ $500 \mathrm{~m})$ gridded methane $\left(\mathrm{CH}_{4}\right)$ emission inventory for Switzerland, which integrates $90 \%$ of the national emission totals reported to the United Nations Framework Convention on Climate Change (UNFCCC) and recent $\mathrm{CH}_{4}$ flux studies conducted by research groups across Switzerland. In addition to anthropogenic emissions, we also include natural and semi-natural $\mathrm{CH}_{4}$ fluxes, i.e., emissions from lakes and reservoirs, wetlands, wild animals as well as uptake by forest soils. National $\mathrm{CH}_{4}$ emissions were disaggregated using detailed geostatistical information on source locations and their spatial extent and process- or area-specific emission factors. In Switzerland, the highest $\mathrm{CH}_{4}$ emissions in 2011 originated from the agricultural sector $\left(150 \mathrm{Gg} \mathrm{CH}_{4} \mathrm{yr}^{-1}\right)$, mainly produced by ruminants and manure management, followed by emissions from waste management ( $15 \mathrm{Gg} \mathrm{CH}_{4} \mathrm{yr}^{-1}$ ) mainly from landfills and the energy sector $\left(12 \mathrm{Gg} \mathrm{CH}_{4} \mathrm{yr}^{-1}\right)$, which was dominated by emissions from natural gas distribution. Compared with the anthropogenic sources, emissions from natural and semi-natural sources were relatively small $\left(6 \mathrm{Gg} \mathrm{CH}_{4} \mathrm{yr}^{-1}\right)$, making up only $3 \%$ of the total emissions
\end{abstract}

in Switzerland. $\mathrm{CH}_{4}$ fluxes from agricultural soils were estimated to be not significantly different from zero (between -1.5 and $0 \mathrm{Gg} \mathrm{CH}_{4} \mathrm{yr}^{-1}$ ), while forest soils are a $\mathrm{CH}_{4}$ sink (approx. $-2.8 \mathrm{Gg} \mathrm{CH}_{4} \mathrm{yr}^{-1}$ ), partially offsetting other natural emissions. Estimates of uncertainties are provided for the different sources, including an estimate of spatial disaggregation errors deduced from a comparison with a global (EDGAR v4.2) and an European (TNO/MACC) $\mathrm{CH}_{4}$ inventory. This new spatially explicit emission inventory for Switzerland will provide valuable input for regional-scale atmospheric modeling and inverse source estimation.

\section{Introduction}

Most of the atmospheric methane $\left(\mathrm{CH}_{4}\right)$ produced in Switzerland results from anthropogenic activities. These emissions are well documented in the Swiss Greenhouse Gas Inventory (SGHGI, FOEN, 2013) that is updated and communicated to the UNFCCC on an annual basis. In contrast, the latest estimate for natural $\mathrm{CH}_{4}$ fluxes including lakes, 
wild animals, wetlands and forest soils (SAEFL, 1996) is outdated and was never compared with actual measurements taken in Switzerland. In 2011, the agricultural sector contributed $84.6 \%$ to the total anthropogenic $\mathrm{CH}_{4}$ emissions of $178 \mathrm{Gg} \mathrm{CH}_{4} \mathrm{yr}^{-1}$, while the waste management and energy sectors added another $8.3 \%$ and $6.8 \%$, respectively (FOEN, 2013). Since $1990, \mathrm{CH}_{4}$ emissions have decreased by about $20 \%$ in Switzerland (FOEN, 2013). One reason is the decline in livestock numbers over the last $20 \mathrm{yr}$, mainly caused by changes in federal legislation. Emissions from natural gas distribution decreased due to the replacement of old infrastructure (Xinmin, 2004). However, this replacement process is now completed (Xinmin, 2004) and, combined with the projected higher demand for natural gas due to the new Swiss energy strategy (SFOE, 2012a), emissions are expected to increase again. Disposal of combustible waste in landfills has been prohibited since 2000 in Switzerland and therefore emissions from this source are decreasing (FOEN, 2013). Counteracting this trend, emissions from biogas production have more than doubled since 1990 and are projected to rise even further (FOEN, 2013). Thus, a reliable baseline inventory for $\mathrm{CH}_{4}$ emissions from anthropogenic activities and natural processes is urgently needed.

Inventory estimates such as those presented in the SGHGI are based on numerous assumptions and statistical data that are associated with large uncertainties in several categories. Hence, validation by independent means is essential. Attempts have been made to constrain regional or national $\mathrm{CH}_{4}$ emissions by atmospheric concentration measurements using boundary-layer budgets (Gallagher et al., 1994; Choularton et al., 1995; Fowler et al., 1996; Beswick et al., 1998; Wratt et al., 2001), inverse emission modeling (Vermeulen et al., 1999; Bergamaschi et al., 2005; Manning et al., 2011; Polson et al., 2011; Wennberg et al., 2012), or by discriminating individual sources with the help of the isotopic signature of $\mathrm{CH}_{4}$ (Levin et al., 1999; Lowry et al., 2001; Miller, 2005). Studies of $\mathrm{CH}_{4}$ fluxes in Switzerland mainly concentrated on measurements at a few selected sites and typically focused on improving process-level understanding rather than on providing representative numbers for national emission budgets. A first attempt was made by Hiller $(2012,2014 b)$ to compare an earlier, preliminary version of the $\mathrm{CH}_{4}$ inventory presented in this paper with $\mathrm{CH}_{4}$ flux estimates based on aircraft measurements in a valley dominated by agriculture, the single most important $\mathrm{CH}_{4}$ source in Switzerland. For this valley it was shown that the measured fluxes were in a similar range as the corresponding inventory values, but clearly more extensive evaluations using our inventory are needed.

In order to model the influence of $\mathrm{CH}_{4}$ emissions on atmospheric concentrations, spatially explicit inventories are needed in addition to total national emissions (Bun et al., 2010). To disaggregate emissions to a higher spatial resolution, detailed knowledge of the location and the activity of each source is required, leading to additional uncertainty (Ciais et al., 2010). In recent years, the increasing targeting of the atmospheric and inverse modeling community on the regional and urban scale has led to a clear trend towards highresolution inventories. Currently, four different $\mathrm{CH}_{4}$ inventories include Switzerland. EDGARv4.2, EDGAR-HTAP and TNO-MACC focus on anthropogenic emissions, NatAir considers only natural and biogenic emissions (details are shown in Table 1); thus, no inventory combines all $\mathrm{CH}_{4}$ sources. $\mathrm{Al}-$ though these inventories have benefited from a considerable increase in resolution (e.g., EDGAR changed in 2009 from $1^{\circ} \times 1^{\circ}$ to $0.1^{\circ} \times 0.1^{\circ}$ ), they are still limited to cell sizes of about $10 \mathrm{~km} \times 10 \mathrm{~km}$. For a spatially heterogeneous country such as Switzerland, this resolution is still too coarse to capture local variations.

The goal of this study was to produce the first gridded, high-resolution $(500 \mathrm{~m} \times 500 \mathrm{~m}) \mathrm{CH}_{4}$ inventory for Switzerland. Anthropogenic emission estimates followed the methodologies of the SGHGI (FOEN, 2013). National totals were either spatially disaggregated across Switzerland using the respective correlated geostatistical data with at least $500 \mathrm{~m} \times 500 \mathrm{~m}$ spatial resolution, or generated in a bottom-up approach using emission factors (EFs). The SAEFL (1996) fluxes were updated and the total emissions for all relevant categories are reported together with their uncertainties. The additional uncertainty at the grid level introduced by the spatial disaggregation was estimated by comparing different inventories. For each source category, a brief review of recent research studies in Switzerland is presented and the results from field studies are compared with the inventory estimates where possible.

\section{Data collection and processing}

Our spatially explicit inventory is based on the SGHGI for anthropogenic emissions and additionally comprises natural fluxes. National emission totals were distributed onto a $500 \mathrm{~m} \times 500 \mathrm{~m}$ grid according to correlated geostatistical data. Natural sources without up-to-date national totals available were up-scaled and spatially attributed using geostatistical data. Emission factors were adapted from the literature, including dedicated studies for Switzerland. The spatially explicit inventory was generated for the year 2011, which is the latest year available from the SGHGI. Sources are represented by positive numbers, sinks by negative numbers.

\subsection{Swiss anthropogenic greenhouse gas inventory (SGHGI)}

The latest submission of the SGHGI to the UNFCCC on 15 April 2013 reports greenhouse gas (GHG) emissions by sources and removals by sinks between 1990 (base year) and 2011 (FOEN, 2013). A detailed description of the institutional arrangements for inventory preparation, data sources and methodologies, uncertainty evaluations as well as quality assurance/quality control (QA/QC) activities are given in the 
Table 1. Existing high-resolution $\mathrm{CH}_{4}$ inventories that include Switzerland.

\begin{tabular}{|c|c|c|c|c|}
\hline & EDGARv4.2 & EDGAR-HTAP & TNO-MACC 2009 & NatAir \\
\hline
\end{tabular}

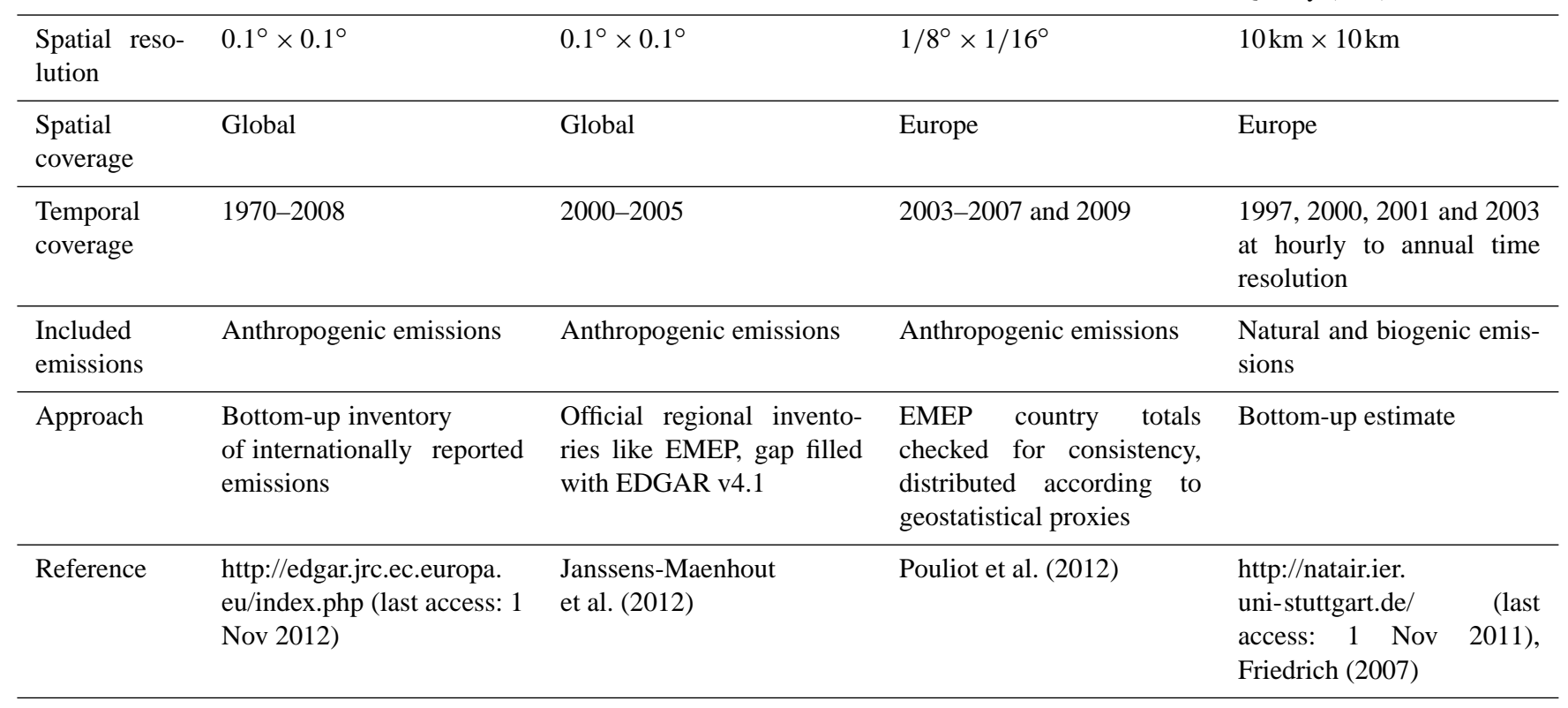

SGHGI (FOEN, 2013). The inventory preparation follows the reporting guidelines developed by the Intergovernmental Panel on Climate Change (IPCC) (IPCC, 1997, 2000, 2003, 2006). To estimate GHG emissions and removals following the IPCC methodology, three approaches differing in complexity (so-called tiers) can be used. The Tier 1 methodology uses generalized default equations and parameters provided by the IPCC guidelines. Tier 2 employs country-specific input data, providing more detail on the underlying processes with regional specificities. Tier 3 is the most complex approach in terms of capturing dynamic processes and their spatial stratification, involving domestic measurements and/or modeling. The UNFCCC encourages parties to develop Tier 3 methods for large sources and sinks as well as for those with temporal trends, the so-called key categories (IPCC, 2000). Switzerland is currently working to include more country-specific information for the next commitment period 2013-2020.

For the spatially explicit inventory, the eight strongest $\mathrm{CH}_{4}$ sources out of a total of 620 listed in the SGHGI (FOEN, 2013) were selected, adding up to about $90 \%$ of all anthropogenic $\mathrm{CH}_{4}$ emissions. These eight sources include emissions from the agricultural sector $(41 \%$ from enteric fermentation of dairy cattle, $17 \%$ from young cattle, $5 \%$ from suckler cows, $2 \%$ from sheep, $9 \%$ from manure of dairy cattle and $5 \%$ of swine), the waste sector (5\% from landfills), and the energy sector (5\% from losses from natural gas distribution), where percentages in parentheses represent the share of the total 2011 anthropogenic emission estimate of $178 \mathrm{Gg} \mathrm{CH}_{4} \mathrm{yr}^{-1}$. Additionally, we also compiled a spatial inventory of the emissions from wastewater treatment plants as these act as strong local sources.

\subsubsection{Agricultural sector}

The largest agricultural source in the SGHGI is 4.A Enteric Fermentation followed by 4.B Manure Management (the headings and numbers correspond to the official nomenclature for reporting, see Table 2). Agricultural residue burning is only a small source in Switzerland and reported in the sector 6. Waste, whereas emissions from agricultural soils, rice production, and burning of savannas are negligible.

The 57600 registered farms manage about one third of Switzerland's area $\left(15000 \mathrm{~km}^{2}\right.$ including Alpine pastures; FSO, 2013) and rear animals equivalent to 1316600 livestock units (FSO, 2011).

Agricultural $\mathrm{CH}_{4}$ emissions from livestock result from the microbial degradation of carbohydrates present in the rumen of ruminants, and to a lesser extent also in the hindgut of all herbivores (Jensen, 1996). Additionally, carbohydrates that 
Table 2. Swiss $\mathrm{CH}_{4}$ emissions in 2011, uncertainty estimate, and changes from 1990 to 2011 for the major source categories listed by the official Nomenclature for Reporting (NFR) codes. The provided uncertainty estimates follow the Tier 1 methodology (IPCC, 2000), represent half of the $95 \%$ confidence interval expressed in percent (IPCC, 1997), and account for uncertainties in emission factors (EFs) and activity data for the individual level or category. Total national emissions exclude the Land Use, Land-Use Change and Forestry sector (LULUCF in italics) as well as International Bunkers (not shown), in accordance with the reporting requirements under the UNFCCC. Methods applied and EFs used are indicated $(\mathrm{D}=$ IPCC Default, T1 = IPCC Tier 1, T2 = IPCC Tier 2, T3 = IPCC Tier 3, CR = CORINAIR, CS = countryspecific). All data for the anthropogenic sources are taken from the national Greenhouse Gas Inventory (FOEN, 2013), while $\mathrm{CH}_{4}$ fluxes from the natural categories are based on estimates presented in this study. The categories indicated with an asterisk are included in our spatially explicit inventory.

\begin{tabular}{|c|c|c|c|c|c|}
\hline $\mathrm{CH}_{4}$ source and sink categories & $\begin{array}{c}2011 \\
{\left[\mathrm{Gg} \mathrm{GH}_{4} \mathrm{yr}^{-1}\right]}\end{array}$ & $\begin{array}{c}\text { Uncertainty } \\
{[\%]}\end{array}$ & $\begin{array}{c}\text { Change since } \\
1990[\%]\end{array}$ & Methods & EFs \\
\hline Anthropogenic & 177.73 & 16 & -20.2 & & \\
\hline 1. Energy & 12.14 & 35 & -58.9 & & \\
\hline A. Fuel Combustion & 3.89 & 35 & -65.9 & $\mathrm{CS}, \mathrm{T} 2, \mathrm{~T} 3$ & CR, CS \\
\hline 3.b Transport; Road Transportation - Gasoline & 1.00 & 35 & -79.3 & & \\
\hline 4.b Other Sectors; Residential - Biomass & 1.43 & 48 & -68.7 & & \\
\hline B. 2 Fugitive Emissions from Fuels; Oil and Natural Gas* & 8.25 & 50 & -54.4 & T3, CS & $\mathrm{CS}$ \\
\hline 2. Industrial Processes (Chemical Industry) & 0.41 & 30 & -10.5 & $\mathrm{CS}, \mathrm{T} 2$ & CS, D \\
\hline 3. Solvent and Other Product Use & NO & & & & \\
\hline 4. Agriculture & 150.43 & 18 & -4.5 & & \\
\hline A Enteric Fermentation* & 119.48 & 18 & -4.8 & $\mathrm{~T} 2$ & $\mathrm{CS}$ \\
\hline B Manure Management* & 30.94 & 54 & -3.2 & $\mathrm{~T} 2$ & CS, D \\
\hline 5. Land Use, Land-Use Change and Forestry (Wildfires in Forest Land) & 0.06 & 70 & -84.9 & $\mathrm{~T} 1$ & CS \\
\hline 6. Waste & 14.72 & 48 & -58.0 & & \\
\hline A Solid Waste Disposal on Land* & 8.61 & 58 & -73.7 & CS, D & CS, D \\
\hline B Wastewater Handling* & 0.48 & 30 & 115.6 & $\mathrm{D}$ & CS,D \\
\hline D Other & 5.04 & 100 & 253.2 & $\mathrm{CS}$ & CS \\
\hline 7. Other (Fire Damage in Buildings and Motor Vehicles) & 0.03 & 30 & 3.9 & $\mathrm{~T} 1$ & $\mathrm{CS}$ \\
\hline Natural and semi-natural & $5.7 /-2.8$ & NA & NA & & \\
\hline Lakes and reservoirs* & 2.3 & NA & NA & \multicolumn{2}{|c|}{ See Sect. 2.2.1 } \\
\hline Wetlands* & 2.3 & NA & NA & \multicolumn{2}{|c|}{ See Sect. 2.2.2 } \\
\hline Wild animals* & 1.1 & NA & NA & \multicolumn{2}{|c|}{ See Sect. 2.2.3 } \\
\hline Agricultural soils & -1.5 to 0 & NA & NA & \multicolumn{2}{|c|}{ See Sect. 2.2.4 } \\
\hline Forest soils* & -2.8 & NA & NA & \multicolumn{2}{|c|}{ See Sect. 2.2.5 } \\
\hline
\end{tabular}

are not digested and thus are excreted as volatile solids can subsequently be converted to $\mathrm{CH}_{4}$ during manure management. Overall, the $\mathrm{CH}_{4}$ production from enteric fermentation is primarily related to feed intake, standardized by using gross energy intake (GE) for inventory purposes. Intake differences quite reliably reflect variations in animal weight and performance (milk yield, growth, and pregnancy) and corresponding differences in $\mathrm{CH}_{4}$ emissions (Soliva, 2006). However, variation in feed composition, i.e., in the substrates for the methanogenic archaea, is not accounted for. $\mathrm{CH}_{4}$ production is assumed to decline when forage is partially replaced with concentrate in the ruminant diet (Beauchemin et al., 2008), but this reduction is often smaller than assumed, and about one third of this reduction may be subsequently compensated for by correspondingly higher manure-derived $\mathrm{CH}_{4}$ emissions (Hindrichsen et al., 2006). Since Swiss ruminant diet types are mostly forage-based, $\mathrm{CH}_{4}$ conversion rates measured in Switzerland are higher than IPCC (2006) default values (Zeitz et al., 2012). On the other hand, experiments on $\mathrm{CH}_{4}$ emissions from Swiss manure manage- ment result in lower emissions than currently estimated in the SGHGI using IPCC (2006) default values (Zeitz et al., 2012). In particular, emissions from liquid manure systems tend to be lower than those currently reported. The influence of animal genotype on the $\mathrm{CH}_{4}$ emission potential is currently being discussed at the global level, but Swiss studies do not indicate significant differences between dairy breeds (Münger and Kreuzer, 2006). In conclusion, preliminary analyses suggest no significant change in $\mathrm{CH}_{4}$ emissions from livestock by applying Swiss-specific EFs (Zeitz et al., 2012), as different under- and overestimates compensate each other. However, this conclusion does not yet consider the potential to reduce GHG emissions using different feeding measures (addition of lipids, plant secondary compounds, etc.; see, e.g., Beauchemin et al., 2008; Staerfl et al., 2012).

For our spatially explicit inventory, emissions were calculated from livestock numbers in 2007, aggregated by farm (agricultural establishment census 2007; FSO, 2009), and multiplied by animal-specific EFs from the Swiss national air pollution database (EMIS, Federal Office for the 
Environment). Emissions for 2007 were then scaled to the 2011 value reported in the SGHGI. Following Swiss husbandry practice, most emissions were assumed to be produced in the stall ( $80 \%$ for cattle, $20 \%$ for sheep, $100 \%$ for swine) and the remaining fraction in the pastures. The agricultural establishment census contains the location of the main farm building at one hectare resolution and was assumed identical to the stable and manure storage location (Kupper et al., 2010). Emissions in pastures were attributed to all grid cells covered by this land-use type (Swiss landuse statistics; FSO GEOSTAT, 2009) within the community of the respective farm. As part of Swiss farming practice, part of the livestock is moved to Alpine pastures in summer. Consequently, the $\mathrm{CH}_{4}$ emissions produced there were also allocated in those Alpine pastures $(\approx 4 \%$ of the agricultural emissions included in the spatially explicit inventory).

\subsubsection{Waste management}

Within the waste management sector, $\mathrm{CH}_{4}$ emissions originate mainly from 6.A Solid Waste Disposal on Land, 6.B Wastewater Handling, and 6.D Other processes, including composting, digestion of organic waste, and biogas upgrading.

\section{Landfills}

Gas production by decomposition of organic material in the anoxic waste body (typically $50-70 \% \mathrm{CH}_{4}(\mathrm{v} / \mathrm{v}), 30-50 \%$ $\mathrm{CO}_{2}$, and trace amounts of other gases; Farquhar and Rovers, 1973) leads to advective and diffusive gas transport within the landfill pore system and eventually to emissions into the atmosphere (e.g., Franzidis et al., 2008).

Recent research activities related to landfill-derived $\mathrm{CH}_{4}$ in Switzerland are limited to the Lindenstock municipal waste landfill near Liestal. This 12 ha landfill received $\approx$ $3.2 \times 10^{6} \mathrm{~m}^{3}$ of household, construction, and commercial waste between 1949 and 1994. Following closure, the waste was capped with a 2 to $2.5 \mathrm{~m}$-thick cover soil consisting primarily of silty loam, and a gas-collection system was installed constructed of vertical and horizontal, partially screened, high-density polyethylene pipes. However, gas collection has not been attempted in recent years, and gas outlets remain closed with screw-cap lids. This is a unique feature of this landfill, as gas-collection systems on several other Swiss landfills are either in continuous operation or absent.

Experiments at Lindenstock compared $\mathrm{CH}_{4}$ fluxes obtained by different methods (Gómez et al., 2009; Eugster and Plüss, 2010; Schroth et al., 2012) at or above the cover-soil surface, as well as below-ground fluxes. Results indicated that the studied section of the landfill was predominantly a net source of $\mathrm{CH}_{4}$, with highest emissions close to the gascollection outlets (daily mean fluxes ranging between 0.05 and $1.5 \mathrm{~g} \mathrm{CH}_{4} \mathrm{~m}^{-2} \mathrm{~d}^{-1}$ ) (Henneberger et al., 2012; Schroth et al., 2012). A net flux of up to $-0.002 \mathrm{~g} \mathrm{CH}_{4} \mathrm{~m}^{-2} \mathrm{~d}^{-1}$ (up- take) was usually observed away from the gas-collection outlets. $\mathrm{CH}_{4}$ efflux from the waste body was highly variable over short distances and time. $\mathrm{CH}_{4}$ oxidation activity in the cover soil was generally high, mitigating most of the produced $\mathrm{CH}_{4}$, but also exhibiting substantial spatial variability (estimated to -1.92 to $-64 \mathrm{~g} \mathrm{CH}_{4} \mathrm{~m}^{-2} \mathrm{~d}^{-1}$ in 2010), being strongest where efflux from the waste body was highest. Mitigation of landfill-derived $\mathrm{CH}_{4}$ in the Lindenstock cover soil is mediated by a highly diverse, abundant methanotrophic community (Henneberger et al., 2012, 2013). Similar experiments during winter indicated stronger net $\mathrm{CH}_{4}$ emissions (up to $2.5 \mathrm{~g} \mathrm{CH}_{4} \mathrm{~m}^{-2} \mathrm{~d}^{-1}$ ) from the studied landfill section (Ugolini et al., 2009). This was primarily attributed to a decrease in oxygen availability within the cover soil as a result of increased soil water content at shallow depths, but also to a decrease in temperature, which both adversely affected the $\mathrm{CH}_{4}$ oxidation activity.

These results from Lindenstock are not sufficiently representative for estimating total landfill emissions in Switzerland, but they broadly agree with previous studies on landfills in Europe and the USA, reporting oxidation activities in a similar but higher range. Hence, cover soils in general provide an effective buffer for landfill-derived $\mathrm{CH}_{4}$, mitigating emissions into the atmosphere as a result of the activity of methanotrophs (Whalen et al., 1990; Boeckx et al., 1996; Börjesson et al., 1998; Chanton et al., 2009; Gebert et al., 2009; Park et al., 2010).

Characteristics of the individual landfills, such as waste composition, dumping period, etc., were not available for Switzerland. Therefore, the national emissions of $8.6 \mathrm{Gg} \mathrm{CH}_{4} \mathrm{yr}^{-1}$ as reported in the SGHGI FOEN (2013) were proportionally distributed to the hectares classified as landfills in the land use statistics (FSO GEOSTAT, 2009) for our spatially explicit inventory.

\section{Wastewater treatment}

$\mathrm{CH}_{4}$ is produced in the sewage system as well as in the anoxic part of the wastewater treatment plant and the upgrading of sewage gas. To our knowledge, no direct wastewater $\mathrm{CH}_{4}$ measurements exist for Switzerland; however, the $\mathrm{CH}_{4}$ emissions can be estimated from the organic load in the wastewater. The chemical oxygen demand (COD) ranges from 100 to $110 \mathrm{gCODperson}{ }^{-1} \mathrm{~d}^{-1}$, with one third each being aerobically respired, converted to $\mathrm{CH}_{4}$, and remaining in the sewage sludge. A large part of the $\mathrm{CH}_{4}$ produced is used for power and heat supply of the wastewater plant, and only about $10 \%$ is directly emitted into the environment. The resulting EF of $0.9 \mathrm{~g} \mathrm{CH}_{4}$ person $^{-1}$ day $^{-1}$ lies within the range of reported conversion rates by Dealman et al. (2012) of $0.08 \%$ to $1.2 \%$ of $\mathrm{kg} \mathrm{CH}_{4}(\mathrm{kgCOD})^{-1}$. The amount of released $\mathrm{CH}_{4}$ also depends on the sewage system (higher with long pipes at low inclination) and the plant type (higher with uncovered anoxic post-digester). Using an average $\mathrm{EF}$ of $0.9 \mathrm{~g} \mathrm{CH}_{4}$ person $^{-1}$ day $^{-1}$ and a 12 
million population equivalent (Swiss population plus industrial wastewater load converted to additional population), annual emissions from wastewater collection and treatment result in about $4 \mathrm{Gg} \mathrm{CH}_{4} \mathrm{yr}^{-1}$. However, a recent publication proposes a higher EF of $1.5 \mathrm{~g} \mathrm{CH}_{4}$ person ${ }^{-1}$ day $^{-1}$, arguing that $\mathrm{CH}_{4}$ production in the sewage system was underestimated (Wunderlin et al., 2013). The resulting $\mathrm{CH}_{4}$ emissions would increase by $50 \%$ to about $6 \mathrm{Gg} \mathrm{CH}_{4} \mathrm{yr}^{-1}$. In contrast, the SGHGI is based on a completely different method reporting only $0.48 \mathrm{Gg} \mathrm{CH}_{4} \mathrm{yr}^{-1}$, because the emissions are estimated from loss rates within the individual plant units and the total $\mathrm{CH}_{4}$ used for energy or biogas production. Hence, emissions from tanks that are not connected to the gas system and emissions in the sewage are not included. To be consistent with the SGHGI, we proportionally distributed the $0.48 \mathrm{Gg} \mathrm{CH}_{4} \mathrm{yr}^{-1}$ to the 854 plants in Switzerland (FOEN, 2012) based on their capacity expressed in population equivalents. However, emissions might turn out up to a factor twelve higher using alternative estimation approaches.

\subsubsection{Energy sector}

Total $\mathrm{CH}_{4}$ emissions in the energy sector are divided into the subcategories 1.A Fuel Combustion, where most emissions originate from road transportation and residential heating, and 1.B Fugitive Emissions from Fuels. The latter emissions largely occur during the transmission of natural gas in pipelines (category 1.B.2 Oil and Natural Gas; FOEN, 2013).

In Switzerland, $12.2 \%$ of the total energy consumption was covered by natural gas in 2011 (SFOE, 2012b). Gas distribution in Switzerland includes $\approx 19000 \mathrm{~km}$ of pipelines, from which $12 \%$ are operated at pressures $>5 \mathrm{bar}, 23 \%$ between 1 and 5 bar, and $65 \%<1$ bar. Another $\approx 6000 \mathrm{~km}$ of pipes guarantee the final distribution to the end user (SGWA, 2012). A large proportion of the transported gas transits Switzerland on the way from the production sites in northern Europe to Italy (Xinmin, 2004).

In the SGHGI, fugitive emissions of natural gas are estimated based on the amount of transported gas as well as on the infrastructure, namely the length, type and pressure of the gas pipelines (FOEN, 2013). Most emissions are assumed to occur during final distribution and consumption, while emissions from welded high-pressure pipes are assumed to be low (Xinmin, 2004). Therefore, emissions reported in the SGHGI were distributed close to the gas consumers for our spatially explicit inventory. Based on the national buildings and dwellings survey (FSO, 2010), the national emissions were proportionally distributed to those areas where natural gas is used for heating, i.e., to each 1 ha grid cell where at least two houses are heated with natural gas. The emissions were subsequently aggregated onto the $500 \mathrm{~m} \times 500 \mathrm{~m}$ grid.

\subsection{Natural and semi-natural $\mathrm{CH}_{4}$ sources and sinks}

The SGHGI only reports anthropogenic $\mathrm{CH}_{4}$ emissions while natural and semi-natural fluxes are omitted, except for wildfires in the Land Use, Land-Use Change and Forestry (LULUCF) sector. $\mathrm{CH}_{4}$ flux estimates reported in the SAFEL report (1996) were updated based on new EF and compiled in our spatially explicit inventory as described below.

\subsubsection{Lakes and reservoirs}

Approximately $3.5 \%$ of Switzerland $\left(1450 \mathrm{~km}^{2}\right)$ is covered by lakes and reservoirs (FSO GEOSTAT, 2009), which can emit significant amounts of $\mathrm{CH}_{4}$ (Bastviken et al., 2011). These $\mathrm{CH}_{4}$ emissions can occur via four main pathways: (1) standard gas exchange at the air-water interface; (2) ebullition (bubbling) from aquatic sediments; (3) turnover of a stratified water column with storage of $\mathrm{CH}_{4}$ in (anoxic) bottom water; and (4) transport by plants in the shallow littoral zones (Chanton and Whiting, 1995; Bastviken et al., 2004). Hydropower reservoirs have an additional fifth emission pathway as they release water for energy production. Often the turbine intakes of a hydropower dam are located in the $\mathrm{CH}_{4}$-rich bottom water of a stratified reservoir, thus $\mathrm{CH}_{4}$ can be emitted via degassing at the turbine or along the downstream river to which the water is released (Kemenes et al., 2007). The most important sink for $\mathrm{CH}_{4}$ in aquatic environments is oxidation, which occurs mostly at oxic/anoxic boundaries in the sediment (e.g., Frenzel et al., 1990) or water column (e.g., Schubert et al., 2010) and can account for a significant reduction in total $\mathrm{CH}_{4}$ produced by decomposition of organic material in a lake before the $\mathrm{CH}_{4}$ reaches the atmosphere.

Measuring all of these $\mathrm{CH}_{4}$ transport pathways and their spatiotemporal variability in a single lake requires immense effort. Thus, often only a subset of all possible pathways is directly measured, while others are either neglected or estimated from literature data. Truly accurate and validated models for estimating $\mathrm{CH}_{4}$ emissions via all these pathways do not exist. An approach that can be used when attempting to estimate $\mathrm{CH}_{4}$ emissions from a large amount of lakes without direct measurements is to use the equations proposed by Bastviken et al. (2004), which estimate diffusion, ebullition, and storage emissions based on comprehensive measurements from a collection of North American and European lakes (see Supplement for details). Bastviken et al. (2004) found significant relationships between the $\mathrm{CH}_{4}$ emission estimates and measurable variables, such as lake area, dissolved organic carbon and phosphorus concentrations, water depth, and the volume of the anoxic fraction of the water column.

Following Bastviken et al. (2004), we estimated diffusion, ebullition and storage emissions of $\mathrm{CH}_{4}$ from the lake areas of all major Swiss water bodies, but made the following modifications. (1) We tripled $\mathrm{CH}_{4}$ emissions from lakes and 
reservoirs shallower than $30 \mathrm{~m}$ based on direct measurements of emissions from a small, shallow lake in the low Alpine region, which indicated high rates of ebullition (Schubert et al., 2012). (2) For the hydroelectric reservoir Lake Wohlen on the Swiss Plateau, we directly used the emission estimate of DelSontro et al. (2010) that was based on a year-long measurement study and results in a value ten times higher than that obtained with the method of Bastviken et al. (2004). No adjustments to any other reservoirs were made as Lake Wohlen may not be a representative system within Switzerland. (3) We provided a rough temporal variability of ebullition emissions by assuming that ebullition occurs only during the warmest half of the year, as DelSontro et al. (2010) found a strong correlation between emissions and seasonal water temperatures. (4) Finally, we assumed ebullition not to be a relevant process in high Alpine lakes at altitudes above 1500 ma.s.l. since they receive only little organic input, have low water temperature, and quite low $\mathrm{CH}_{4}$ concentrations in the water column (Diem et al., 2012). The resulting emission factors are summarized in Table S1. The above-presented modifications suggest that other factors in addition to those proposed by Bastviken et al. (2004) may need to be considered for estimating $\mathrm{CH}_{4}$ emissions from lakes and reservoirs in the future.

The locations and areas of Swiss lakes and reservoirs were taken from the primary surfaces of the digital version of the Swiss topographical map at 1:25000 scale in vector format (VECTOR25; Swisstopo, 2004), while the depths for lakes $>0.1 \mathrm{~km}^{2}$ were obtained from FOEN (2007a). We included all lakes that are contained in the Swiss water bodies information system (GEWISS; FOWG, 2000). Water depth data could not be found for 652 out of 798 lakes. Therefore, we assumed that the depth of lakes $<0.2 \mathrm{~km}^{2}$ (678 lakes) is less than $30 \mathrm{~m}$. Lake altitude was taken from the digital elevation model (FSO GEOSTAT, 2006). In total, we found that lakes $>0.1 \mathrm{~km}^{2}$ emit $2.1 \mathrm{Gg} \mathrm{CH}_{4} \mathrm{yr}^{-1}$, with a $21 \%\left(0.4 \mathrm{Gg} \mathrm{CH}_{4} \mathrm{yr}^{-1}\right)$ share from hydroelectric reservoirs. Smaller water bodies contribute another $0.2 \mathrm{Gg} \mathrm{CH}_{4} \mathrm{yr}^{-1}$.

\subsubsection{Wetlands}

Wetlands are the largest natural source of $\mathrm{CH}_{4}$ globally, where it is produced by microbial decomposition of organic material under anoxic conditions. However, wetlands have become rare in Switzerland $\left(0.5 \%, 200 \mathrm{~km}^{2}\right.$, of the land area today compared to $6 \%$ in 1800; FOEN, 2007b). In our study, we also considered wetland areas of a mixed ecosystem type and hence a ten times larger area (see Table S2). They are classified as wetlands on the basis of their high biodiversity, protected by the Swiss legislation on the protection of mires, rather than by their hydrogeological properties that would better reflect their characteristics in terms of $\mathrm{CH}_{4}$ fluxes.

Most information on wetland $\mathrm{CH}_{4}$ fluxes originate from the Arctic, boreal, and tropical zones, and it is not trivial to translate those results to Swiss wetlands. An important complication is the fact that even in moist environments the vegetated surface may act as a net sink for atmospheric $\mathrm{CH}_{4}$ when water saturation in the soil is limited to deeper layers or when drainage ditches lower the average water table (e.g., Moore and Roulet, 1993). In most cases it can be expected that periods where wetlands are a sink for $\mathrm{CH}_{4}$ are restricted to a few warm and dry weeks a year, which reduces the overall annual $\mathrm{CH}_{4}$ emissions from such ecosystems compared with permanently waterlogged wetlands.

In Swiss fens, $\mathrm{CH}_{4}$ emission rates ranging from 100 to $330 \mathrm{mg} \mathrm{CH}_{4} \mathrm{~m}^{-2} \mathrm{~d}^{-1}$ have been reported for the summer months (Alpine fen at Göschener Alp, Liebner et al., 2012). Constant emissions between 0.12 and $31 \mathrm{mg} \mathrm{CH}_{4} \mathrm{~m}^{-2} \mathrm{~d}^{-1}$ were also found from glacier forefields with calcareous bedrock (Nauer et al., 2012), while mires on siliceous bedrock were either a weak source of $\mathrm{CH}_{4}(38 \%$ of all cases), neutral (31\%), or a $\mathrm{CH}_{4} \operatorname{sink}(31 \% ;-0.14$ to $-1.1 \mathrm{mg} \mathrm{CH}_{4} \mathrm{~m}^{-2} \mathrm{~d}^{-1}$; Nauer et al., 2012). Even in the case of large emissions from calcareous glacier forefields, Nauer et al. (2012) observed that roughly $90 \%$ of the $\mathrm{CH}_{4}$ produced in the deeper soil was oxidized before it reached the soil surface and the atmosphere. This agrees with other studies, which indicate that in the top centimeters of the soil above the water table, where oxygen is abundant, most of the $\mathrm{CH}_{4}$ produced by methanogenic archaea is oxidized and hence the flux of $\mathrm{CH}_{4}$ to the atmosphere is substantially lower than what microorganisms produce (e.g., King et al., 1998).

For our spatially explicit inventory, $\mathrm{CH}_{4}$ emissions from Swiss wetlands were estimated from the wetland areas in Switzerland and literature-based EFs available for different wetland types as summarized in Table S2. Different types of wetland areas were determined from the national inventories of raised bogs, fens and mires (FOEN, 2008b, 2010) as well as of riparian landscapes (FOEN, 2008a). Additionally, the wetland core and sprawl areas reported in the national ecological network (FOEN, 2011b) were included in the analysis since these contain additional wetlands of regional and local importance. For the emission estimate, polygons were mapped to a $100 \mathrm{~m} \times 100 \mathrm{~m}$ raster. Grid cells classified by one of the different types of wetlands were subsequently multiplied by the corresponding EF. If a grid cell belonged to more than one wetland type, the one with highest priority was selected. The priority refers to the level of detail of the data set (e.g., specification of different zones within a wetland) and the importance of a wetland type for $\mathrm{CH}_{4}$ emissions. As a final step, the data were averaged to the $500 \mathrm{~m} \times 500 \mathrm{~m}$ grid. In total, Swiss wetlands are estimated to emit approximately $2.3 \mathrm{Gg} \mathrm{CH}_{4} \mathrm{yr}^{-1}$.

\subsubsection{Wild animals}

Red and roe deer, Alpine chamois and Alpine ibex are the most abundant wild living ruminants in Switzerland. $\mathrm{CH}_{4}$ emissions from these wild animals were estimated from the 
animal population estimates at cantonal (state) level in 2011 (except for Canton of Jura: 2006 and Canton of Vaud: 2009) (FOEN, 2011a). We multiplied these animal populations by the respective species-dependent EF in SAEFL (1996) (see Table S3). The spatial distribution depends on the habitat of the animals. While red deer prefer dense and open forest, roe deer prefer dense forest. Alpine chamois prefer unproductive vegetation as well as rocks and scree, while Alpine ibex mainly thrive on rocks and scree. The respective land cover types were selected from the Swiss land-use statistic (FSO GEOSTAT, 2009). Additionally, the locations of these Alpine habitats were restricted to altitudes above $1500 \mathrm{~m}$ a.s.l. (FSO GEOSTAT, 2006).

The number of large wild animals (260000 red and roe deer, Alpine chamois and Alpine ibex) in Switzerland (FOEN, 2011a) is substantially less than the 1580000 cattle (FSO, 2011) in the agricultural sector. Moreover, wild animals are smaller in size and show a smaller energy uptake than cattle. This results in a comparatively low emission estimate of $1.1 \mathrm{Gg} \mathrm{CH}_{4} \mathrm{yr}^{-1}$.

SAFEL (1996) also reported substantial emissions of $2.8 \mathrm{Gg} \mathrm{CH}_{4} \mathrm{yr}^{-1}$ from rodents. Radar measurements of the mice density on Swiss fields resulted in an average of 9000 mice $\mathrm{km}^{-2}$ (AGFF, 2012), while the rabbit density was estimated as 2.7 rabbits km ${ }^{-2}$ (Zellweger-Fischer, 2012). Scaled to the $10500 \mathrm{~km}^{2}$ agricultural area in Switzerland (FSO, 2011 ), this translates to $\approx 94.5$ mio. mice and 28350 rabbits. Multiplied by the EFs of $0.26 \mathrm{~g} \mathrm{CH}_{4}$ mouse $\mathrm{yr}^{-1}$ (Jensen, 1996) and $80 \mathrm{~g} \mathrm{CH}_{4} \mathrm{rabbit}^{-1} \mathrm{yr}^{-1}$ (IPCC, 2006), the annual emissions result in $0.027 \mathrm{Gg} \mathrm{CH}_{4} \mathrm{yr}^{-1}$, which is far less than previously assumed and does not represent a significant contribution to the emissions from wild animals. Hence, rodents were not included in our spatially explicit inventory.

\subsubsection{Agricultural soils}

Two counteracting processes - methanogenesis and methanotrophy - drive the net exchange of $\mathrm{CH}_{4}$ between agricultural soils and the atmosphere. In Switzerland, the agricultural sector comprises typical crop production on arable land (18\%), comparatively large areas of grasslands (49\%) and Alpine summer pastures $(33 \%)$, adding up to $15000 \mathrm{~km}^{2}$, corresponding to more than one third of the total area of Switzerland (FSO GEOSTAT, 2009; FSO, 2011). Several studies conducted at managed grasslands and Alpine pastures in Switzerland have reported small $\mathrm{CH}_{4}$ uptake rates by soils (Hartmann et al., 2010; Stiehl-Braun et al., 2011; Imer et al., 2013; Merbold et al., 2013), which is also supported by other studies (Mosier et al., 1991; Flessa et al., 1998; Ineson et al., 1998; van den Pol-van Dasselaar et al., 1999; Kammann et al., 2001). The $\mathrm{CH}_{4}$ fluxes depend on multiple drivers such as water-filled pore space, soil and air temperatures, nutrient availability, management activity such as fertilizer application or tilling, and soil texture. These drivers are site-specific, but also change temporally at a sin- gle site. Recent results from three grassland sites in Switzerland reveal large temporal and spatial variations in $\mathrm{CH}_{4}$ fluxes from managed ecosystems (Imer et al., 2013), ranging from a small sink $\left(-1.37 \mathrm{mg} \mathrm{CH}_{4} \mathrm{~m}^{-2} \mathrm{~d}^{-1}\right)$ to a slight source $\left(0.59 \mathrm{mg} \mathrm{CH}_{4} \mathrm{~m}^{-2} \mathrm{~d}^{-1}\right)$ on a daily timescale, and averaging to an annual mean flux of $-0.21 \mathrm{mg} \mathrm{CH}_{4} \mathrm{~m}^{-2} \mathrm{~d}^{-1}$ and $-0.30 \mathrm{mg} \mathrm{CH}_{4} \mathrm{~m}^{-2} \mathrm{~d}^{-1}$ for two sites with almost year-round measurements (Imer et al., 2013). To the best of our knowledge, these are the only two year-round data sets that exist in Switzerland, leading to large uncertainties when up-scaling to the total area of managed agroecosystems. We expect the annual net $\mathrm{CH}_{4}$ flux for Switzerland to range between 0 and $-1.5 \mathrm{Gg} \mathrm{CH}_{4} \mathrm{yr}^{-1}$ (EF: $-0.14 \pm 0.14 \mathrm{mg} \mathrm{CH}_{4} \mathrm{~m}^{-2} \mathrm{~d}^{-1}$; Freibauer, 2003) for the $10500 \mathrm{~km}^{2}$ agricultural land, excluding Alpine pastures, being a small sink. This is comparable in magnitude with other natural fluxes, but does not significantly contribute to the total $\mathrm{CH}_{4}$ budget of Switzerland. Since $\mathrm{CH}_{4}$ uptake across the agricultural areas is highly spatially variable, we did not attempt to distribute this small $\mathrm{CH}_{4}$ sink spatially across Switzerland in our study.

\subsubsection{Forest soils}

The net $\mathrm{CH}_{4}$ flux of forest soils is again dominated by the two counteracting processes, methanogenesis and methanotrophy. The available literature suggests that forests soils generally are a larger $\mathrm{CH}_{4}$ sink than agricultural soils due to higher soil gas diffusivity in these systems (Smith et al., 2000). $\mathrm{CH}_{4}$ fluxes over Swiss forest soils have been investigated only very recently (Frey et al., 2011; Gundersen et al., 2012; Hiltbrunner et al., 2012). Interestingly, uptake rates of $-1.5 \mathrm{mg} \mathrm{CH}_{4} \mathrm{~m}^{-2} \mathrm{~d}^{-1}$ for forest soils were found, which changed to a $\mathrm{CH}_{4}$ source of up to $2 \mathrm{mg} \mathrm{CH}_{4} \mathrm{~m}^{-2} \mathrm{~d}^{-1}$ when soils were compacted by forestry machinery (Frey et al., 2011). These soil emissions persisted for several years (S. Zimmermann, personal communication, 2012), but were limited to relatively small areas compared to the total forest extent. Effects of soil compaction were therefore not considered in our spatially explicit inventory.

To estimate the $\mathrm{CH}_{4}$ uptake by Swiss forests, we followed a method developed by Hobi et al. (2011). Forest cover was derived from the land-use statistics (FSO GEOSTAT, 2009), and forest type information was taken from the $25 \mathrm{~m} \times 25 \mathrm{~m}$ forest mixture data set (FSO GEOSTAT, 2004) and thereafter aggregated to $100 \mathrm{~m} \times 100 \mathrm{~m}$. $\mathrm{CH}_{4}$ uptake rates differ significantly between evergreen $\left(-0.46 \pm 0.27 \mathrm{mg} \mathrm{CH}_{4} \mathrm{~m}^{-2} \mathrm{~d}^{-1}\right)$ and deciduous forest soils $\left(-1.12 \pm 68 \mathrm{mg} \mathrm{CH}_{4} \mathrm{~m}^{-2} \mathrm{~d}^{-1}\right)$, according to the literature reviewed by Hobi et al. (2011). Forest areas were therefore multiplied by the uptake rate appropriate for the type of forest at a 1 ha resolution. For mixed forests an average rate was used. Finally, the data were averaged to a $500 \mathrm{~m} \times 500 \mathrm{~m}$ grid. Overall, our estimate of $\mathrm{CH}_{4}$ net flux of forest soils is $-2.8 \mathrm{Gg} \mathrm{CH}_{4} \mathrm{yr}^{-1}$ for 2011 . 


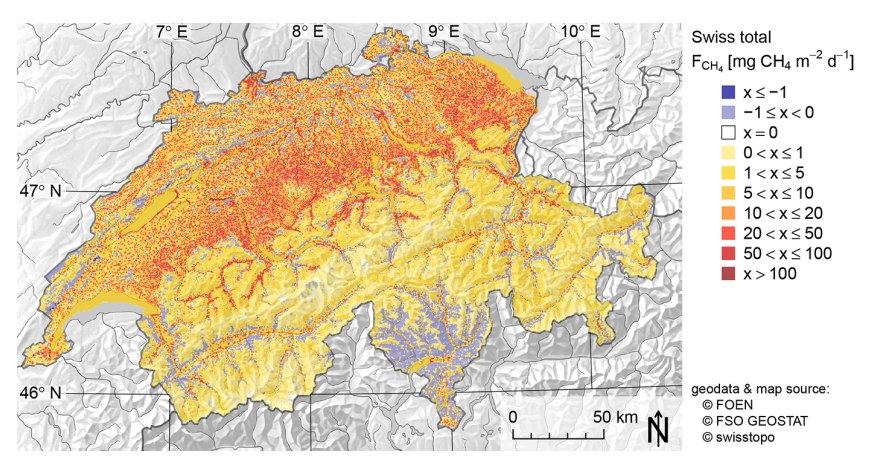

Fig. 1. Our spatially explicit Swiss $\mathrm{CH}_{4}$ emission inventory including both anthropogenic and natural $\mathrm{CH}_{4}$ sources.

\section{Results and discussion}

\subsection{Spatially explicit $\mathrm{CH}_{4}$ inventory}

Anthropogenic emissions are strongly dominating total Swiss $\mathrm{CH}_{4}$ emissions and mostly originate from agriculture (see Table 2). Hence, the highest emissions are observed in the southern part of the Swiss Plateau, an area dominated by livestock farming between the pre-Alps to the south and the Jura mountains to the north, covering approx. $30 \%$ of Switzerland (Figs. 1 and 2a). Due to the proximity to the Alps, this region receives more precipitation than the rest of the Swiss Plateau and is therefore less suited for the production of vegetables and cereal, which are mainly cultivated in the northern and western parts of the Swiss Plateau. The central and northern parts of the Swiss Plateau are densely populated and consequently less land is dedicated to agriculture, which corresponds to relatively low emissions in this region. In the Alps, agricultural activity is concentrated on the valley floors. During the summer months, part of the livestock is moved to Alpine pastures for grazing to save the resources in the valley for the winter. This practice is part of the traditional Swiss three-stage farming system (Bätzing, 2003) and therefore $\mathrm{CH}_{4}$ emissions can also be found in relatively remote areas of the Alps.

$\mathrm{CH}_{4}$ emissions from waste management (Fig. 2b) are more abundant in regions with high population density. This also applies to the energy sector (Fig. 2c), where highest $\mathrm{CH}_{4}$ emissions occur in urban areas because natural gas is distributed to private households for cooking and heating.

Natural and semi-natural $\mathrm{CH}_{4}$ emissions from lakes, wetlands, and wild animals (Fig. 2d-f) as well as the uptake by forest soils (Fig. 2f) are considerably lower than anthropogenic emissions (Table 2). Natural lakes in Switzerland are remnants from previous glaciations. The largest lakes are located in the lowlands, while many small lakes are found throughout the country. Reservoirs are mainly situated in Alpine areas to exploit the descent for hydropower generation (Fig. 2f). Since the large wetlands in the floodplains were drained for agricultural use in the 19th and 20th centuries, the highest emissions from this ecosystem type are limited today to shore areas and to hilly landscapes where agriculture is less favorable (Fig. 2d). Wild animals are more abundant in rural areas with continuous forests, the preferred habitat for many species. Alpine ibex and chamois also populate remote and sparsely vegetated mountainous areas (Fig. 2e). Forests cover mountain slopes up to the timberline, protecting from natural hazards. At lower elevations, forests were often converted into agricultural land during the last centuries, but some remained and are protected today by law. While wild animals living in the forest are a source of $\mathrm{CH}_{4}$, the forest soil acts as a sink. Deciduous forests are limited to lower elevations, whereas evergreen forests dominate at higher elevations. Due to the lower uptake rate of evergreen forests, $\mathrm{CH}_{4}$ uptake by forest soil tends to decrease with elevation.

Our spatially explicit inventory is available from http: //doi.pangaea.de/10.1594/PANGAEA.828262 (Hiller et al., 2014a).

\subsection{Comparison with other inventories}

The EDGAR v4.2 inventory and the TNO/MACC inventory in Fig. 3 show spatial distributions of total anthropogenic $\mathrm{CH}_{4}$ emissions over Switzerland for the latest available years of 2008 and 2009, respectively. These maps can be qualitatively compared with the total emissions of our inventory presented in Fig. 1, where anthropogenic emissions make up more than $95 \%$.

The total emission of EDGAR v4.2 clipped to the domain of Switzerland amounts to $236 \mathrm{Gg} \mathrm{CH}_{4} \mathrm{yr}^{-1}$ for 2008 , consistent with the country total reported by EDGAR v4.2 for Switzerland. This total is almost $30 \%$ higher than the $183 \mathrm{Gg} \mathrm{CH}_{4} \mathrm{yr}^{-1}$ reported in the SGHGI for the same year. The TNO/MACC inventory adds up to $191 \mathrm{Gg} \mathrm{CH}_{4} \mathrm{yr}^{-1}$ over the domain of Switzerland in 2009, which is close to the $180 \mathrm{Gg} \mathrm{CH}_{4} \mathrm{yr}^{-1}$ in the SGHGI for 2009 (FOEN, 2013). The difference between EDGAR and TNO/MACC likely reflects the fact that EDGAR is an independent inventory applying its own methodologies for the collection of activity data, application of emission factors, and spatial allocation. The TNO/MACC inventory, in contrast, is scaled to total emissions reported by the individual countries. In both inventories, the spatial allocation of the emissions is based on different and less detailed geostatistical information than available in our study. Fig. 4 presents scatter plots of the pixel values of the EDGAR and TNO/MACC inventories versus our inventory mapped to the respective resolution of the coarser inventory. Scatter plots were created for both total emissions and for different categories separately. For the scatterplot, we used the subsectors that represent the emissions in our inventory best, while the comparison of Swiss totals per sector is based on all emissions of each sector reported in the respective inventory. In general, the agreement is significantly better for TNO/MACC than for EDGAR, except for the waste sector. The EDGAR 


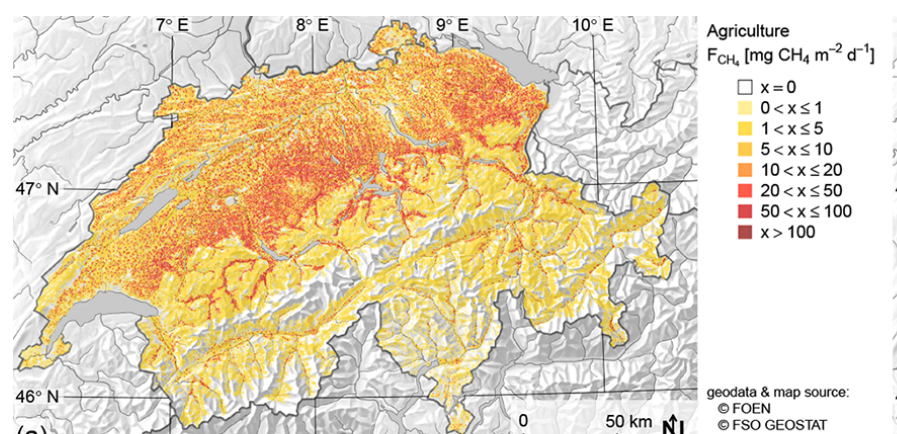

(a)
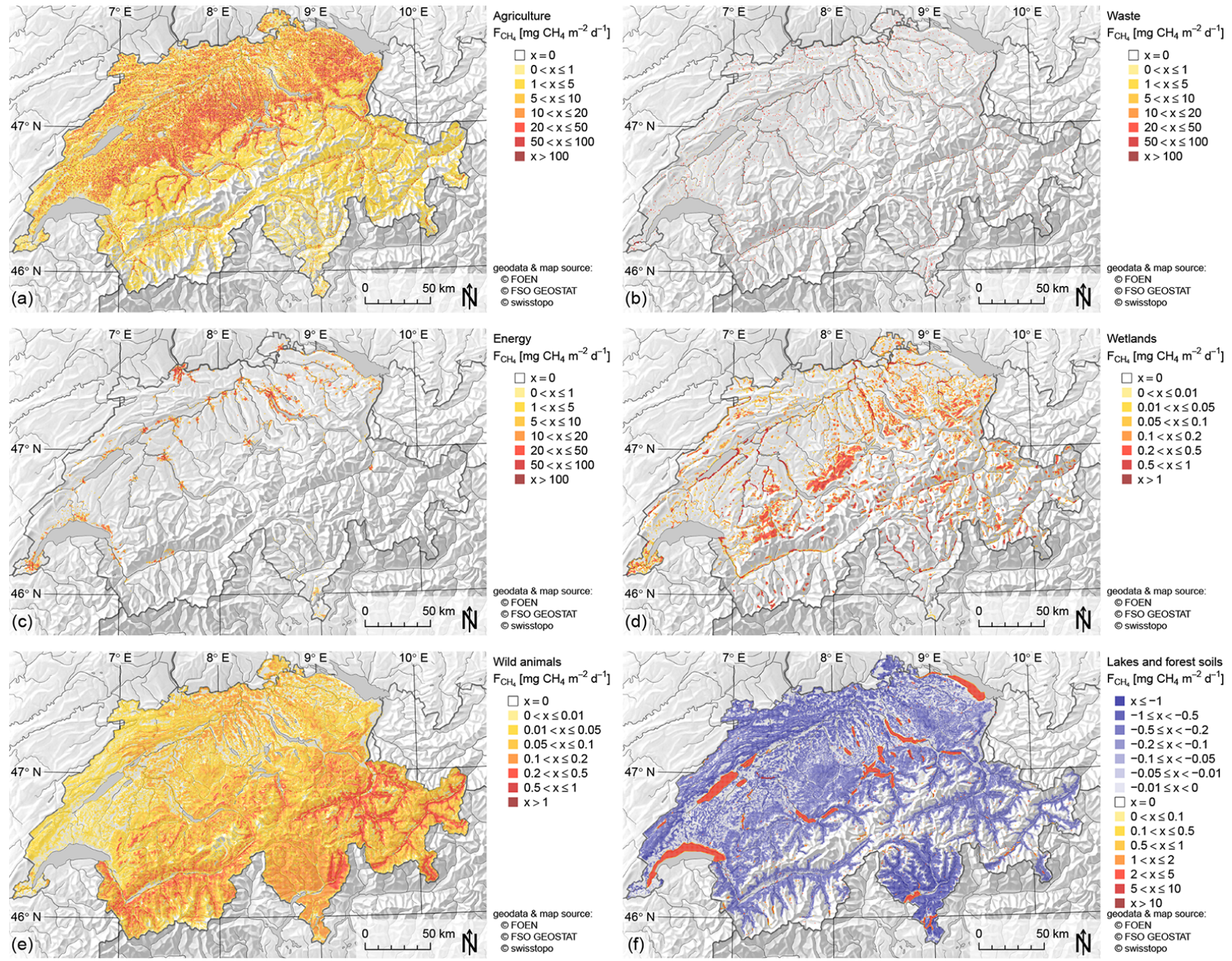

Fig. 2. Individual layers of the inventory presented in Fig. 1. Note that the scale for anthropogenic fluxes of the agricultural sector (a), the waste sector (b) and the energy sector (c) are a factor 10 to 100 larger than that for natural and semi-natural fluxes from wetlands (d), wild animals (e), and forest soil and lakes (f).

inventory tends towards higher fluxes as compared to our inventory, especially for the waste and energy sectors. EDGAR emissions for waste $\left(30 \mathrm{Gg} \mathrm{CH}_{4} \mathrm{yr}^{-1}\right)$ and energy ( $44 \mathrm{GgCH}_{4} \mathrm{yr}^{-1}$ ) are substantially higher than in the SGHG inventory (waste: $17 \mathrm{Gg} \mathrm{CH}_{4} \mathrm{yr}^{-1}$, energy: $13 \mathrm{Gg} \mathrm{CH}_{4} \mathrm{yr}^{-1}$ ). The relative difference for agricultural emissions is smaller, $162 \mathrm{Gg} \mathrm{CH}_{4} \mathrm{yr}^{-1}$ for EDGAR compared with $153 \mathrm{Gg} \mathrm{CH}_{4} \mathrm{yr}^{-1}$ in the SGHGI. The TNO/MACC inventory compares well also at the sectorial level (agriculture: $163 \mathrm{Gg} \mathrm{CH}_{4} \mathrm{yr}^{-1}$, waste: $17 \mathrm{Gg} \mathrm{CH}_{4} \mathrm{yr}^{-1}$, and energy: $10 \mathrm{Gg} \mathrm{CH}_{4} \mathrm{yr}^{-1}$ in 2009) against SGHGI (agriculture: $151 \mathrm{Gg} \mathrm{CH}_{4} \mathrm{yr}^{-1}$, waste: $16 \mathrm{Gg} \mathrm{CH}_{4} \mathrm{yr}^{-1}$, and energy: $13 \mathrm{Gg} \mathrm{CH}_{4} \mathrm{yr}^{-1}$ in 2009). Emissions in the EDGAR inventory are higher in densely populated regions (see Fig. S1 for a population density map) but lower in agriculturally dominated regions compared with our inventory (Fig. 3c), suggesting that EDGAR allocates emissions too strongly to population density, consistent with the much higher values assigned to fuel distribution and waste disposal. Spatial differences are less pronounced between the TNO/MACC inventory and our inventory (Fig. 3d). In particular, the TNO/MACC inventory correctly identifies the regions of farming in the southern parts of the Swiss Plateau, but the emissions tend to be higher in these areas and lower in the mountains compared with our inventory. These spatial differences are further assessed in Sect. 3.3.1 to obtain a rough estimate of the uncertainty associated with the spatial disaggregation.

For natural $\mathrm{CH}_{4}$ emissions, we only compare our country totals with numbers reported in an earlier study for Switzerland (SAEFL, 1996). Compared with that study, our estimates are considerably lower. Forests were considered 

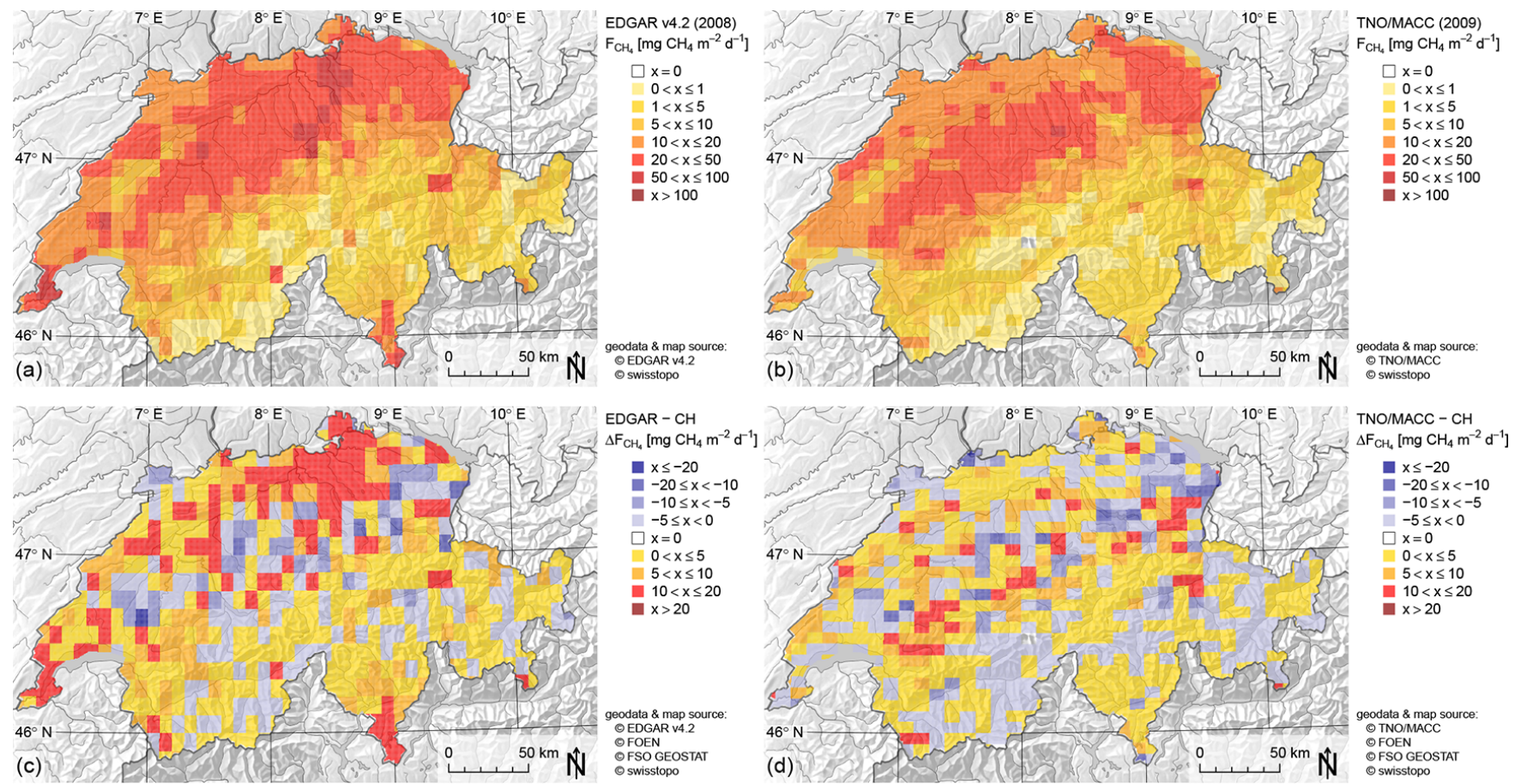

Fig. 3. Total anthropogenic $\mathrm{CH}_{4}$ emissions over Switzerland according to the EDGAR v4.2 inventory for the year 2008 (a) and the TNO/MACC inventory for the year 2009 (b). Panels (c) and (d) are absolute differences from the total anthropogenic emissions in our inventory (Fig. 1).

a significant $\mathrm{CH}_{4}$ source $\left(50 \mathrm{Gg} \mathrm{CH}_{4} \mathrm{yr}^{-1}\right)$ in the former study, which was based on much more limited information. However, in the past two decades, no evidence for such strong $\mathrm{CH}_{4}$ emissions could be found in Switzerland, and hence our updated estimate suggests that forests are a net $\mathrm{CH}_{4}$ sink instead (net flux of -2.3 to $-3.2 \mathrm{GgCH}_{4} \mathrm{yr}^{-1}$ ) (Hobi, 2011). Moreover, contributions from small wild animals, namely rodents, are estimated to be much lower ( $\left.0.027 \mathrm{Gg} \mathrm{CH}_{4} \mathrm{yr}^{-1}\right)$ than previously $\left(2.8 \mathrm{Gg} \mathrm{CH}_{4} \mathrm{yr}^{-1}\right)$. Our findings indicate that agricultural soils may act as a small net sink (net flux of -1.5 to $0 \mathrm{Gg} \mathrm{CH}_{4} \mathrm{yr}^{-1}$ ), while emissions of up to $2.1 \mathrm{GgCH}_{4} \mathrm{yr}^{-1}$ were previously attributed to this type of ecosystem. In contrast, lakes had been estimated to be $\mathrm{CH}_{4}$ neutral, whereas our findings suggest that they are a source of $2.3 \mathrm{Gg} \mathrm{CH}_{4} \mathrm{yr}^{-1}$. Only the previous estimates for large wild animals $\left(0.9 \mathrm{Gg} \mathrm{CH}_{4} \mathrm{yr}^{-1}\right)$ and wetlands (1.2 $\mathrm{Gg} \mathrm{CH}_{4} \mathrm{yr}^{-1}$ ) compare well with our study (1.1 $\mathrm{Gg} \mathrm{CH}_{4} \mathrm{yr}^{-1}$ and $2.3 \mathrm{Gg} \mathrm{CH}_{4} \mathrm{yr}^{-1}$, respectively). Overall, the natural and semi-natural $\mathrm{CH}_{4}$ emissions estimated in our study $\left(5.7 \mathrm{Gg} \mathrm{CH}_{4} \mathrm{yr}^{-1}\right)$ are only about $10 \%$ of those reported by SAEFL (1996), but equate to $3 \%$ of the total $\mathrm{CH}_{4}$ emissions in Switzerland.

\subsection{Uncertainties of the inventory}

For many purposes, and in particular for inverse modeling studies in which emission inventories are used as a priori es- timates, it is important to quantify not only the distribution of the emissions but also their uncertainty. In the SGHGI (FOEN, 2013), an uncertainty is determined for each emission category based on errors associated with the activity data and the EFs. The combined uncertainties are listed in Table 2 together with the mean emissions for 2011. The uncertainty of the annual total emissions can then be computed as the square root of the sum of squares of the individual uncertainties, assuming uncorrelated errors. The uncertainty of the total Swiss anthropogenic $\mathrm{CH}_{4}$ emissions is estimated to only $16 \%$ (see Table 2), which is largely due to the low uncertainty of $18 \%$ assigned by the SGHGI to the main emission source, 4.A Enteric Fermentation. It is interesting to note that this uncertainty is smaller than the difference between the SGHGI and the EDGAR v4.2 inventory.

For the uncertainty of emissions of a given grid cell at a given time, additional errors need to be considered, including errors associated with the spatial disaggregation and with the temporal variability as described in the following.

\subsubsection{Spatial uncertainty}

Uncertainties associated with the spatial disaggregation are difficult to assess. They depend on the accuracy of the spatial data sets, on quantization errors due to the use of discrete classes, on the relative weights assigned to individual sources, and on the often crude assumptions made for spatial 

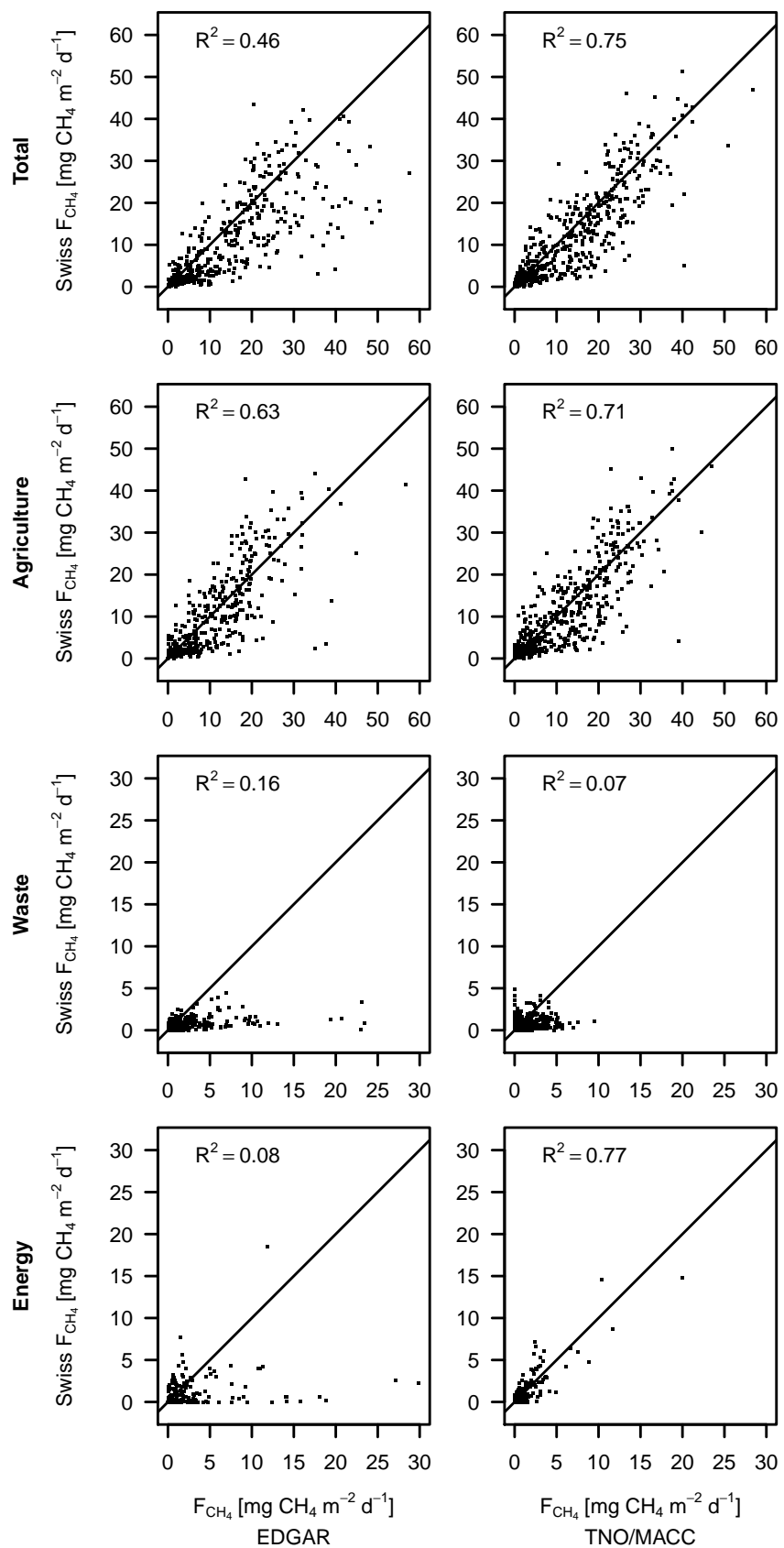

Fig. 4. Scatterplot between all pixel values in the EDGAR v42 and TNO/MACC inventories in Switzerland versus our inventory reduced to the respective resolution of the coarser inventory. Plots are shown for total emissions as well as for the sectors agricultural (EDGAR: IPCC_4A, IPCC4B and TNO/MACC: SNAP code 10), waste (EDGAR: IPCC_6A_6C, IPCC_6B and TNO/MACC: SNAP code 9) and energy (EDGAR: IPCC_1B2b and TNO/MACC: SNAP code 5) separately. The solid lines indicate the 1:1 relationship. The panels were scaled to show as much detail as possible and hence a few very large emissions were omitted.

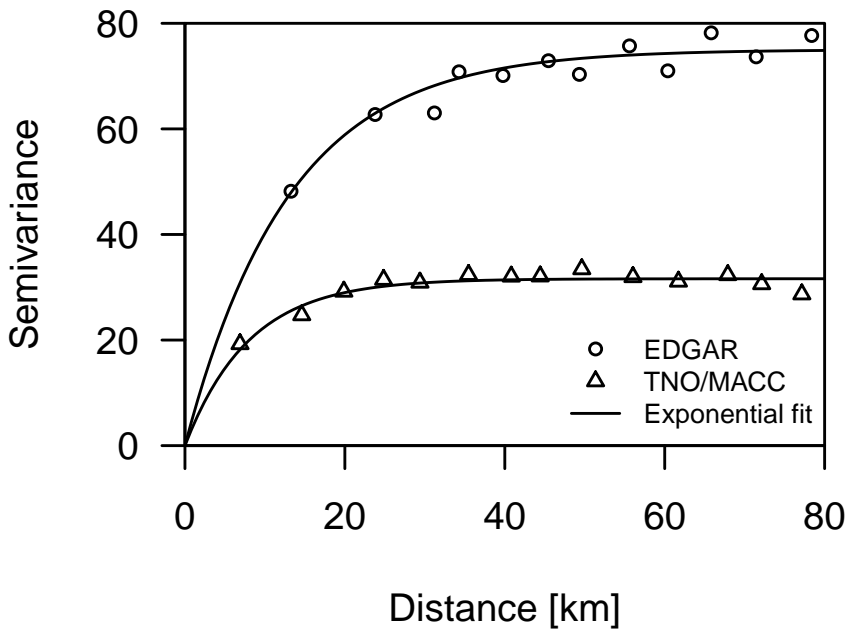

Fig. 5. Semivariogram of the differences between the EDGAR v4.2 and TNO/MACC inventories and our inventory. Also shown are exponential fits to the data (see text for further details).

disaggregation. Here we try to quantify the uncertainty of the emissions at the grid-cell level together with an error correlation length scale in a way that is consistent with the uncertainty of the country total of $16 \%$. For simplicity, uncertainties are only specified in terms of relative uncertainty of the grid cell total, but no distinction is made between different categories contributing to the total. The error covariance matrix $C$, which is an important input for inverse emission estimation, can then easily be formulated with diagonal elements

$C_{i i}=\left(f E_{i}\right)^{2}$

and off-diagonal elements

$C_{i j}=f E_{i} f E_{j} e^{-h / L}$

where $E_{i}$ is the total emission in grid cell $i$ (the 2-D grid cell indices are combined here into a single index $i), f$ is the relative uncertainty, $h$ is the horizontal distance between grid cells $i$ and $j$, and $L$ is the error correlation length scale. The total emission of the country is given by

$E_{\mathrm{tot}}=\sum_{i} E_{i}$

and the uncertainty of the total by

$\sigma\left(E_{\mathrm{tot}}\right)=\sqrt{\sum_{i} \sum_{j} C_{i j}}$.

The error correlation length $L$ was determined by comparing the spatial representation of the emissions in our inventory with that in EDGAR and TNO/MACC, all scaled to the same country total. The relative differences between the inventories are thus assumed to be a measure of the uncertainty 
associated with the spatial disaggregation. The relative uncertainty factor $f$ was finally chosen so that the relative uncertainty $\sigma\left(E_{\text {tot }}\right) / E_{\text {tot }}$ is $16 \%$. To determine a representative error correlation length scale, we analyzed the variogram of the residuals $R$, where $R=E$ (this study) $-E$ (REF), the difference between emissions in our spatially explicit inventory $E$ (this study) and emissions in a reference inventory $E(\mathrm{REF})$ (EDGAR or TNO/MACC) (Fig. 5). A variogram describes the variance of the difference of a spatial variable $R$, i.e., $\operatorname{var}(R(x)-R(x+h))$ as a function of the distance $h$ (Cressie, 1993). The standard deviation of the residuals is larger for EDGAR than for TNO/MACC, which also results in a higher sill (see Fig. 5). As described in Lin and Gerbig (2005), a correlation length scale $L$ can then be derived by fitting an exponential variogram model to the raw variogram. The length scale $L$ obtained in this way was $13.0 \mathrm{~km}$ for EDGAR v4.2 and $8.0 \mathrm{~km}$ for TNO/MACC, which is close to the grid sizes of the two inventories, suggesting that their limited resolution is a constraining factor and that the true correlation length may be even smaller.

Assuming that the smaller correlation length scale of $8 \mathrm{~km}$ is more realistic, we obtain a value for the relative uncertainty $f$ of $130 \%$. Emissions in individual grid cells thus have a large uncertainty and could well be double or half as large as estimated.

\subsubsection{Temporal variability}

Our spatially explicit inventory only includes annual mean emissions, but no seasonal and diurnal cycles due to a lack of suitable data. Nevertheless, we will briefly discuss the available temporal information relevant to our inventory to estimate the importance of temporal variability.

In the agricultural sector, livestock numbers are reported once a year in April, and seasonal fluctuations are only on the order of $\pm 3 \%$, with census data slightly above the annual mean (Bretscher, 2010). Within the traditional Swiss threestage farming system, cattle are moved to Alpine meadows in summer to save the fertile valley floor for crop and winter fodder production. Hence, the spatial allocation of $\mathrm{CH}_{4}$ emissions from ruminants changes between summer and winter. In addition, $\mathrm{CH}_{4}$ emissions from ruminants depend on animal metabolism; thus, emissions peak following feed intake with a delay of a few hours and therefore display a diurnal pattern. Kinsman et al. (1995), for example, reported an average $20 \%$ higher emission during the day than during the night, while Gao et al. (2011a, b) observed a diurnal peak-topeak variation of up to a factor of two following the feeding rhythm. Seasonal $\mathrm{CH}_{4}$ flux variations of about $20 \%$ were attributed to lower emissions from manure at lower temperatures.
Emissions from manure are lowest at low temperatures and increase with longer storage duration, peaking only after about two months (Hindrichsen et al., 2005, 2006; Klevenhusen et al., 2010). The storage period before application is typically longer in winter, but lower storage temperatures likely dominate the influence on $\mathrm{CH}_{4}$ production. Manure storage practice further influences $\mathrm{CH}_{4}$ emissions (Külling et al., 2001, 2002, 2003). Higher than average emissions from farmyard manure are compensated for by lower emissions from urine-rich slurry, and on average do not differ significantly compared with complete slurry. Hence, these differences are of no relevance compared with the effects of storage period and temperature.

Landfills in Switzerland are covered by a soil layer; therefore, no large seasonal temperature fluctuations are expected within the deposited waste. However, the cover soil, where $\mathrm{CH}_{4}$ is oxidized by methanotrophs, undergoes seasonal temperature fluctuations. More importantly, moisture positively influences $\mathrm{CH}_{4}$ production in the waste body and inhibits $\mathrm{CH}_{4}$ uptake in the cover soil (Chanton and Liptay, 2000). Both factors are expected to lead to higher $\mathrm{CH}_{4}$ emissions in winter than in summer (Klusman and Dick, 2000). Nevertheless, the available information is insufficient to quantify seasonal fluctuations of $\mathrm{CH}_{4}$ emissions from Swiss landfills in general.

A large proportion of natural gas is used for heating and therefore consumption is more than four times higher in January than in July (VSG, 2012). $\mathrm{CH}_{4}$ emissions from leaking pipelines are therefore expected to be higher in winter than in summer, but no reliable data are available for proposing a seasonal cycle of these emissions.

Lake $\mathrm{CH}_{4}$ emissions may exhibit a strong seasonal cycle similar to that found in a Swiss reservoir, where emissions were positively correlated with water temperature (DelSontro et al., 2010). In addition, turnover of a seasonally stratified water column can also contribute significantly to the annual $\mathrm{CH}_{4}$ emissions from lakes (Schubert et al., 2010), a quite common process in Swiss lakes. Thus, both processes lead to a pronounced seasonal cycle in $\mathrm{CH}_{4}$ emissions from water bodies in temperate zones, with higher emissions during summer than during winter (Sect. 2.2.1).

The above-listed diurnal and seasonal cycles indicate that observed $\mathrm{CH}_{4}$ fluxes on a single day at a given time may differ significantly from the annual mean fluxes reported in our inventory, although the variations are probably smaller than those of other trace gases such as $\mathrm{NO}_{\mathrm{x}}$, which are dominated by traffic, heating, and other strongly varying activities. For the main emission sources (agriculture, landfills, gas losses) the available information is, unfortunately, not sufficient to provide specific time functions. In the absence of such information, inverse modeling studies need to make assumptions about the potential amplitude and correlation structure of such variations to specify realistic a priori uncertainties. 


\subsubsection{Scale dependency}

When processing a spatially explicit inventory, a spatial resolution needs to be defined. For practical reasons it was decided to use a resolution of $500 \mathrm{~m} \times 500 \mathrm{~m}$, which is considerably better than the resolutions of a few kilometers typically used in regional-scale inverse modeling. Note that the input data were usually available at a higher resolution of $100 \mathrm{~m} \times 100 \mathrm{~m}$, and estimates were first obtained for this higher resolution and then averaged to the $500 \mathrm{~m} \times 500 \mathrm{~m}$ grid. In many cases, the specific choice of spatial scale does not affect the total emissions estimated for a country. This is true for example of ruminant emissions where the total only depends on the number of ruminants but not on the granularity of their distribution within the country. Emissions from ecosystems such as wetlands, however, may critically depend on the chosen scale, in particular if they are estimated with an ecosystem model where the fluxes depend non-linearly on the spatial resolution of the input data. This was shown for example by Zhu et al. (2013), who found $42 \%$ higher wetland $\mathrm{CH}_{4}$ emissions when running their biogeochemistry model at $5 \mathrm{~km} \times 5 \mathrm{~km}$ resolution as compared to a simulation at $100 \mathrm{~km} \times 100 \mathrm{~km}$ resolution. They explained the difference by subgrid-scale variations in the water table that are smoothed out at a lower spatial resolution. In our case, we do not rely on a biogeochemistry model but on estimates of emission fluxes determined for specific wetland ecosystems, multiplied by the areas covered by these ecosystems in each grid cell. Nevertheless, these estimates may be biased if they are based on non-representative emission fluxes. Determining representative fluxes is particularly difficult for ecosystems, where the fluxes may vary on very small spatial scales. For example, DelSontro (2011) observed $\mathrm{CH}_{4}$ flux variations across Lake Wohlen covering more than two orders of magnitude in $\mathrm{CH}_{4}$ flux within a few tens of meters. It is therefore of great importance to combine individual flux measurements into values that are representative of the whole ecosystem (in this case a lake) before using them in an inventory. When finally building a gridded inventory, methods should be avoided that introduce artificial scale dependencies. Such problems are generated for instance when grid cells are assigned to a single land-use type, as shown, e.g., by Zhao and Liu (2013), but can be avoided using for example a mosaic approach that divides each cell into fractional contributions of all land-use classes (Mahrt and Sun (1995), Avissar and Pielke, 1989). We largely avoided such scale dependencies by first determining the land-use coverage of individual ecosystems based on high-resolution $(100 \mathrm{~m} \times 100 \mathrm{~m}$ or better) data sets before distributing the corresponding fluxes over the grid cells of the inventory.

\subsubsection{Needs for building more realistic regional and national inventories}

Regional and national inventories rely on spatial and temporal integration of local fluxes. Many studies are performed at a local scale to investigate the driving processes and often only cover short time periods of a few weeks or are only made in specific seasons. To obtain more representative results, we strongly recommend extending such measurements to complete years or even multiple years to include intra- and inter-annual variations. Even though fluxes deviating from the mean are more interesting for understanding the underlying processes, information on representative fluxes for given ecosystems is more valuable for building realistic inventories. The development of process-based models that result in spatially resolved flux estimates may also contribute to better inventories. At the same time, measurements integrating $\mathrm{CH}_{4}$ fluxes over larger areas approximating the spatial resolution of the inventory are preferred for deriving emission factors. These recommendations are not limited to natural fluxes. Emission factors to estimate anthropogenic methane fluxes rely in the majority of cases on laboratory measurements. The total methane emissions of, e.g., a plant are rarely measured directly. Such direct measurements are especially desirable for revealing the true emission of sectors where different emission estimates result in large differences. Knowing the true total emissions would also help to investigate the efficiency of mitigation measures, as certain pathways might be missed when only investigating the known individual methane-producing processes.

\section{Conclusions}

A spatially explicit high-resolution $\mathrm{CH}_{4}$ inventory was developed for Switzerland for the year 2011. This is the first comprehensive inventory at national level synthesizing most of the available Swiss data sets on anthropogenic as well as on natural and semi-natural fluxes. Anthropogenic emissions of $177 \mathrm{Gg} \mathrm{CH}_{4} \mathrm{yr}^{-1}$ in 2011 are by far larger than the emissions from all natural and semi-natural sources, which were estimated to only $5.7 \mathrm{GgCH}_{4} \mathrm{yr}^{-1}$, an order of magnitude less than an estimate reported in an earlier study on natural sources in Switzerland (SAEFL, 1996). Forest soils are estimated to be a net sink with a net flux of $-2.8 \mathrm{GgCH}_{4} \mathrm{yr}^{-1}$ and agricultural soils are estimated to be $\mathrm{CH}_{4}$ neutral or a small sink with a net flux between -1.5 and $0 \mathrm{GgCH}_{4} \mathrm{yr}^{-1}$ for agricultural soils, partially offsetting the natural emissions. In total, Switzerland acted as a net $\mathrm{CH}_{4}$ source of $180 \mathrm{Gg} \mathrm{CH}_{4} \mathrm{yr}^{-1}$ in 2011 . With a share of nearly $85 \%$, agricultural emissions are by far the most important anthropogenic source in Switzerland, followed by the waste and energy sectors. The uncertainty of the total anthropogenic emissions is estimated to be only $16 \%$, which is largely a result of the low uncertainty assigned to the largest single $\mathrm{CH}_{4}$ source 
- enteric fermentation of ruminants. Detailed geospatial information is available for Switzerland, thereby allowing the spatial allocation of the individual emission sources. Information on temporal variability of $\mathrm{CH}_{4}$ emissions, however, is very sparse and currently insufficient for prescribing diurnal and seasonal variations, an aspect that should be better addressed in future studies.

This inventory will provide invaluable input for regionalscale atmospheric modeling and inverse source estimation, which are urgently needed for independent validation of inventories based on atmospheric measurements. The spatial disaggregation of other $\mathrm{CH}_{4}$ sources currently not covered by this inventory, especially from biogas production and composting, might become more critical in the future with the expected increase in the relative importance of these sources. The methodology suggested here is not specific to Switzerland and could be used to derive similar inventories for other countries, provided that country-specific emission factors are used where necessary and detailed geostatistical data are available.

\section{Supplementary material related to this article is available online at http://www.biogeosciences.net/11/ 1941/2014/bg-11-1941-2014-supplement.pdf.}

Acknowledgements. We thank Martina Alig and Mireille Faist for their input on $\mathrm{CH}_{4}$ emissions from biogas production and composting as well as Christoph Ort, Ivo Strahm, and Pascal Wunderlin on emissions from wastewater treatment. The many $\mathrm{CH}_{4}$ flux measurements on lakes would not have been possible without the help of Beat Müller, Oliver Scheidegger, Gijs Nobbe, Zwyssig Alois, Michael Schurter, Daniel McGinnis, Sebastian Sobek, and Peter Plüss and were supported by Swiss National Science Foundation grant nos. 200020-112274 and 200021-120112. The contribution of Ruth Henneberger and Martin Schroth on landfills was supported by the European Science Foundation EUROCORES Program EuroEEFG, project MECOMECON, with funds from the Swiss National Science Foundation under grant no. 31EE30-131170. Soil $\mathrm{CH}_{4}$ emissions were carried out with project GHG Europe funded by the European Union Seventh Framework Program (FP7/2007-2013) under grant agreement no. 244122 (GHG-Europe). Jacqueline Stieger was supported by grant no. 200021-129866 awarded by the Swiss National Science Foundation. This synthesis project as well as the joint project MAIOLICA were funded by the Competence Center Environment and Sustainability (CCES) of ETH Zurich.

Edited by: P. Stoy

\section{References}

AGFF: Mäuse Radar: Übersicht Erhebungen 2012, Arbeitsgemeinschaft zur Förderung des Futterbaues (AGFF)/Agroscope Reckenholz Tänikon Research Station (ART), available at: http://www.agff.ch/deutsch/publikationen/maeusebekaempfung/ maeuse-radar-2012.html (last access: 13 March 2013), 2012.

Avissar, R., and Pielke, R. A.: A Parameterization of heterogeneous land surfaces for atmospheric numerical models and its impact on regional meteorology. Mon. Wea. Rev., 117, 2113-2136, 1989.

Bastviken, D., Cole, J., Pace, M., and Tranvik, L.: Methane emissions from lakes: dependence of lake characteristics, two regional assessments, and a global estimate, Global Biogeochem. Cy., 18, GB4009, doi:10.1029/2004GB002238, 2004.

Bastviken, D., Tranvik, L. J., Downing, J. A., Crill, P. M., and Enrich-Prast, A.: Freshwater methane emissions offset the continental carbon sink, Science, 331, 593-596, doi:10.1038/ngeo1211, 2011.

Bätzing, W.: Die Alpen: Geschichte und Zukunft einer Europäischen Kulturlandschaft, 3rd edn., C. H. Beck oHG, München, 431 pp., 2003.

Beauchemin, K. A., Kreuzer, M., O’Mara, F., and McAllister, T. A.: Nutritional management for enteric methane abatement: a review, Aust. J. Exp. Agr., 48, 21-27, 2008.

Bergamaschi, P., Krol, M., Dentener, F., Vermeulen, A., Meinhardt, F., Graul, R., Ramonet, M., Peters, W., and Dlugokencky, E. J.: Inverse modelling of national and European $\mathrm{CH}_{4}$ emissions using the atmospheric zoom model TM5, Atmos. Chem. Phys., 5, 2431-2460, doi:10.5194/acp-5-2431-2005, 2005.

Beswick, K. M., Simpson, T. W., Fowler, D., Choularton, T. W., Gallagher, M. W., Hargreaves, K. J., Sutton, M. A., and Kaye, A.: Methane emissions on large scales, Atmos. Environ., 32, 32833291, 1998.

Boeckx, P., Van Cleemput, O., and Villaralvo, I.: Methane emission from a landfill and the methane oxidising capacity of its covering soil, Soil Biol. Biochem., 28, 1397-1405, doi:10.1016/S00380717(96)00147-2, 1996.

Börjesson, G., Sundh, I., Tunlid, A., Frostegard, A., and Svensson, B. H.: Microbial oxidation of $\mathrm{CH}_{4}$ at high partial pressures in an organic landfill cover soil under different moisture regimes, FEMS Microbiol. Ecol., 26, 207-217, doi:10.1111/j.15746941.1998.tb00506.x, 1998.

Bretscher, D.: Agricultural $\mathrm{CH}_{4}$ and $\mathrm{N}_{2} \mathrm{O}$ emissions in Switzerland: QA/QC, Agroscope Reckenholz Tänikon Research Station (ART), 56, available at: http://www.bafu.admin.ch/ climatereporting/00545/01913/index.html?lang=en (last access: 13 March 2013), 2010.

Bun, R., Hamal, K., Gusti, M., and Bun, A.: Spatial GHG inventory at the regional level: accounting for uncertainty, Climatic Change, 103, 227-244, doi:10.1007/s10584-010-9907-5, 2010.

Chanton, J. and Liptay, K.: Seasonal variation in methane oxidation in a landfill cover soil as determined by an in situ stable isotope technique, Global Biogeochem. Cy., 14, 51-60, 2000.

Chanton, J. P. and Whiting, G. J.: Trace gas exchange in freshwater and coastal marine environments: ebullition and transport by plants, in: Biogenic Trace Gases: Measuring Emissions from Soil and Water, edited by: Matson, P. A. and Harriss, R. C., Blackwell Science, 98-125, 1995. 
Chanton, J. P., Powelson, D. K., and Green, R. B.: Methane oxidation in landfill cover soils, is a $10 \%$ default value reasonable?, J. Environ. Qual., 38, 654-663, 2009.

Choularton, T. W., Gallagher, M. W., Bower, K. N., Fowler, D., Zahniser, M., Kaye, A., Monteith, J. L., and Harding, R. J.: Trace gas flux measurements at the landscape scale using boundary-layer budgets, Philos. T. Roy. Soc. A, 351, 357-369, doi:10.1098/rsta.1995.0039, 1995.

Ciais, P., Paris, J. D., Marland, G., Peylin, P., Piao, S. L., Levin, I., Pregger, T., Scholz, Y., Friedrich, R., Rivier, L., Houwelling, S., and Schulze, E. D.: The European carbon balance. Part 1: fossil fuel emissions, Glob. Change Biol., 16, 1395-1408, doi:10.1111/j.1365-2486.2009.02098.x, 2010.

Cressie, N. A. C.: Statistics for Spatial Data, John Wiley and Sons, New York, 900 pp., 1993.

Daelman, M. R. J., Van Voorthuizen, E. M., Van Dongen, U. G. J. M., Volcke, E. I. P., and Van Loosdrecht, M. C. M.: Methane emission during municipal wastewater treatment, Water Res., 46, 3657-3670, doi:10.1016/j.watres.2012.04.024, 2012.

DelSontro, T., McGinnis, D. F., Sobek, S., Ostrovsky, I., and Wehrli, B.: Extreme methane emissions from a Swiss hydropower reservoir: contribution from bubbling sediments, Environ. Sci. Technol., 44, 2419-2425, doi:10.1021/es9031369, 2010.

Diem, T., Koch, S., Schwarzenbach, S., Wehrli, B., and Schubert, C. J.: Greenhouse gas emissions $\left(\mathrm{CO}_{2}, \mathrm{CH}_{4}\right.$, and $\left.\mathrm{N}_{2} \mathrm{O}\right)$ from several perialpine and alpine hydropower reservoirs by diffusion and loss in turbines, Aquat. Sci., 74, 619-635, doi:10.1007/s00027-012-0256-5, 2012.

Eugster, W. and Plüss, P.: A fault-tolerant eddy covariance system for measuring $\mathrm{CH}_{4}$ fluxes, Agr. Forest Meteorol., 150, 841-851, doi:10.1016/j.agrformet.2009.12.008, 2010.

Farquhar, G. J. and Rovers, F. A.: Gas production during refuse decomposition, Water Air Soil Poll., 2, 483-495, doi:10.1007/BF00585092, 1973.

Flessa, H., Wild, U., Klemisch, M., and Pfadenhauer, J.: Nitrous oxide and methane fluxes from organic soils under agriculture, Eur. J. Soil Sci., 49, 327-335, doi:10.1046/j.13652389.1998.00156.x, 1998.

FOEN: Seen in der Schweiz, Federal Office for the Environment (FOEN), available at: http://www.bafu.admin.ch/hydrologie/ 01835/02118/index.html?lang=de\&download=NHzLpZeg7t, Inp6I0NTU04212Z6ln1acy4Zn4Z2qZpnO2Yuq2Z6gpJCEdoF_ gmym162epYbg2c_JjKbNoKSn6A-- (last access: 13 March 2013), 2007a.

FOEN: Zustand und Entwicklung der Moore in der Schweiz, in Umwelt-Zustand, vol. UZ-0730-D, Federal Office for the Environment (FOEN), 97 pp., $2007 \mathrm{~b}$.

FOEN: Bundesinventar der Auengebiete von nationaler Bedeutung, Federal Office for the Environment (FOEN), available at: http://www.bafu.admin.ch/gis/02911/07403/index.html? lang=de (last access: 28 March 2013), 2008a.

FOEN: Bundesinventar der Hoch- und Übergangsmoore von nationaler Bedeutung, Federal Office for the Environment (FOEN), available at: http://www.bafu.admin.ch/gis/02911/07403/index. html?lang=de (last access: 28 March 2013), 2008b.

FOEN: Bundesinventar der Flachmoore von nationaler Bedeutung, Federal Office for the Environment (FOEN), avail- able at: http://www.bafu.admin.ch/gis/02911/07403/index.html? lang=de (last access: 28 March 2013), 2010.

FOEN: Eidgenössische Jagdstatistik, Federal Office for the Environment (FOEN) available at: http://www.wild.uzh.ch/jagdst/ (last access: 13 March 2013), 2011a.

FOEN: Nationales ökologisches Netzwerk (REN: Lebensraum Feuchtgebiet), Federal Office for the Environment (FOEN), available at: http://www.bafu.admin.ch/gis/02911/07403/index. html?lang=de (last access: 28 March 2013), $2011 \mathrm{~b}$.

FOEN: Kläranlagen-Datenbank (wastewater treatment plant database), Federal Office for the Environment (FOEN), 2012.

FOEN: Switzerland's greenhouse gas inventory 1990-2011, Submission of 15 April 2013 under the United Nations Framework Convention on Climate Change and under the Kyoto Protocol, Federal Office for the Environment (FOEN), available at: http://www.bafu.admin.ch/climatereporting/00545/ 12558/index.html?lang=en, last access: 15 April 2013, 2013.

FOWG: Gewässerinformationssystem Schweiz GEWISS: Struktur und Adressierung digitaler Gewässernetze, Federal Office for Water and Geology (FOWG), available at: http://www.bafu.admin.ch/hydrologie/01835/02114/ 02116/index.html?lang=en\&download=NHzLpZeg7t, lnp6I0NTU04212Z61n1ad1IZn4Z2qZpnO2Yuq2Z6gpJCEdoF hGym162epYbg2c_JjKbNoKSn6A (last access: 2 June 2013), 21 pp., 2000.

Fowler, D., Hargreaves, K. J., Choularton, T. W., Gallagher, M. W., Simpson, T., and Kaye, A.: Measurements of regional $\mathrm{CH}_{4}$ emissions in the UK using boundary layer budget methods, Energ. Convers. Manage., 37, 769-775, 1996.

Franzidis, J.-P., Héroux, M., Nastev, M., and Guy, C.: Lateral migration and offsite surface emission of landfill gas at City of Montreal landfill site, Waste Manage. Res., 26, 121-131, doi:10.1177/0734242X07085752, 2008.

Freibauer, A.: Regionalised inventory of biogenic greenhouse gas emissions from European agriculture, Eur. J. Agron., 19, 135160, doi:10.1016/S1161-0301(02)00020-5, 2003.

Frenzel, P., Thebrath, B., and Conrad, R.: Oxidation of methane in the oxic surface layer of a deep lake sediment (Lake Constance), FEMS Microbiol. Lett., 73, 149-158, doi:10.1016/03781097(90)90661-9, 1990.

Frey, B., Niklaus, P. A., Kremer, J., Lüscher, P., and Zimmermann, S.: Heavy-machinery traffic impacts methane emissions as well as methanogen abundance and community structure in oxic forest soils, Appl. Environ. Microb., 77, 6060-6068, doi:10.1128/AEM.05206-11, 2011.

Friedrich, R.: NATAIR: Improving and applying methods for the calculation of natural and biogenic emissions and assessment of impacts to the air quality, available at: http://natair.ier. uni-stuttgart.de/NatAir_Final_Activity_Report.pdf (last access: 13 March 2013), 193 pp., 2007.

FSO: Landwirtschaftliche Betriebszählung (agricultural establishment census) 2007, Federal Statistical Office (FSO), 2009.

FSO: Gebäude- und Wohnungserhebung (buildings and dwellings survey) 2000, ha-grid, Federal Statistical Office (FSO), 2010.

FSO: Landwirtschaftliche Betriebszählungen und landwirtschaftliche Betriebsstrukturerhebungen, Federal Statistical Office (FSO), available at: http://www.sbv-usp.ch/de/statistik/ (last access: 13 March 2013), 2011. 
FSO: Schweizer Landwirtschaft Taschenstatistik 2013, Federal Statistical Office (FSO), available at: http://www.bfs.admin.ch/bfs/ portal/de/index/news/publikationen.Document.167626.pdf (last access: 31 May 2013), 35 pp., 2013.

FSO GEOSTAT: Waldmischungsgrad der Schweiz 1992/97, Federal Statistical Office (FSO), 2004.

FSO GEOSTAT: Geländedaten (digital elevation model), Federal Statistical Office (FSO), available at: http: //www.bfs.admin.ch/bfs/portal/de/index/dienstleistungen/ geostat/datenbeschreibung/gelaendedaten.html (last access: 2 June 2013), 2006.

FSO GEOSTAT: Land use statistics, (Arealstatistik) 1992/97, hagrid, Federal Statistical Office (FSO), 2009.

Gallagher, M. W., Choularton, T. W., Bower, K. N., Stromberg, I. M., Beswick, K. M., Fowler, D., and Hargreaves, K. J.: Measurements of methane fluxes on the landscape scale from a wetland area in North Scotland, Atmos. Environ., 28, 2421-2430, doi:10.1016/1352-2310(94)90394-8, 1994.

Gao, Z., Yuan, H., Ma, W., Li, J., Liu, X., and Desjardins, R. L.: Diurnal and seasonal patterns of methane emissions from a dairy operation in North China Plain, Adv. Meteorol., 190234, doi:10.1155/2011/190234, 2011a.

Gao, Z., Yuan, H., Ma, W., Liu, X., and Desjardins, R. L.: Methane emissions from a dairy feedlot during the fall and winter seasons in Northern China, Environ. Pollut., 159, 1183-1189, 2011 b.

Gebert, J., Singh, B. K., Pan, Y., and Bodrossy, L.: Activity and structure of methanotrophic communities in landfill cover soils, Environ. Microbiol. Rep., 1, 414-423, doi:10.1111/j.17582229.2009.00061.x, 2009.

Gómez, K. E., Gonzalez-Gil, G., Lazzaro, A., and Schroth, M. H.: Quantifying methane oxidation in a landfill-cover soil by gas push-pull tests, Waste Manage., 29, 2518-2526, doi:10.1016/j.wasman.2009.05.011, 2009.

Gundersen, P., Christiansen, J. R., Alberti, G., Brüggemann, N., Castaldi, S., Gasche, R., Kitzler, B., Klemedtsson, L., Lobo-doVale, R., Moldan, F., Rütting, T., Schleppi, P., Weslien, P., and Zechmeister-Boltenstern, S.: The response of methane and nitrous oxide fluxes to forest change in Europe, Biogeosciences, 9, 3999-4012, doi:10.5194/bg-9-3999-2012, 2012.

Hartmann, A. A., Buchmann, N., and Niklaus, P. A.: A study of soil methane sink regulation in two grasslands exposed to drought and $\mathrm{N}$ fertilization, Plant Soil, 342, 265-275, doi:10.1007/s11104-010-0690-x, 2010.

Henneberger, R., Lüke, C., Mosberger, L., and Schroth, M. H.: Structure and function of methanotrophic communities in a landfill-cover soil, FEMS Microbiol. Ecol., 81, 52-65, doi:10.1111/j.1574-6941.2011.01278.x, 2012.

Henneberger, R., Chiri, E., Blees, J., Niemann, H., Lehmann, M. F., and Schroth, M. H.: Field-scale labelling and activity quantification of methane-oxidizing bacteria in a landfill-cover soil, FEMS Microbiol. Ecol., 83, 392-401, doi:10.1111/j.15746941.2012.01477.x, 2013.

Hiller, R. V.: Greenhouse Gases - From the Ecosystem Scale to a Regional Integration, available at: http://e-collection.library. ethz.ch/view/eth:5927 (last access: 28 February 2013), ETH Zurich, 179 pp., 2012.

Hiller, R. V., Bretscher, D., DelSontro, T., Diem, T., Eugster, W., Henneberger, R., Hobi, S., Hodson, E., Imer, D., Kreuzer, M., Künzle, T., Merbold, L., Niklaus, P. A., Rihm, B., Schel- lenberger, A., Schroth, M. H., Schubert, C. J., Siegrist, H., Stieger, J., Buchmann, N., and Brunner, D.: Spatially explicit methan inventory for Switzerland with $500 \mathrm{~m} \times 500 \mathrm{~m}$ resolution for 2011, (NetCDF $25 \mathrm{MB}$ ). Dataset \#828262, doi:10.1594/PANGAEA.828262, 2014a.

Hiller, R. V., Neininger, B., Brunner, D., Gerbig, C., Bretscher, D., Künzle, T., Buchmann, N., and Eugster, W.: Aircraft-based $\mathrm{CH}_{4}$ flux estimates for validation of emissions from an agriculturally dominated area in Switzerland, J. Geophys. Res.-Atmos., doi:10.1002/2013JD020918, 2014b.

Hiltbrunner, D., Zimmermann, S., Karbin, S., Hagedorn, F., and Niklaus, P. A.: Increasing soil methane sink along a 120year afforestation chronosequence is driven by soil moisture, Glob. Change Biol., 18, 3664-3671, doi:10.1111/j.13652486.2012.02798.x, 2012.

Hindrichsen, I. K., Wettstein, H. R., Machmüller, A., Jörg, B., and Kreuzer, M.: Effect of the carbohydrate composition of feed concentratates on methane emission from dairy cows and their slurry, Environ. Monit. Assess., 107, 329-350, doi:10.1007/s10661005-3008-3, 2005.

Hindrichsen, I. K., Wettstein, H. R., Machmüller, A., and Kreuzer, M.: Methane emission, nutrient degradation and nitrogen turnover in dairy cows and their slurry at different milk production scenarios with and without concentrate supplementation, Agr. Ecosyst. Environ., 113, 150-161, 2006.

Hobi, S.: Spatial allocation of methane sources and sinks in Switzerland, ETH Zurich, 76 pp., 2011.

Imer, D., Merbold, L., Eugster, W., and Buchmann, N.: Temporal and spatial variations of $\mathrm{CO}_{2}, \mathrm{CH}_{4}$ and $\mathrm{N}_{2} \mathrm{O}$ fluxes at three differently managed grasslands, Biogeosciences Discuss., 10, 2635-2673, doi:10.5194/bgd-10-2635-2013, 2013.

Ineson, P., Coward, P. A., and Hartwig, U. A.: Soil gas fluxes of $\mathrm{N}_{2} \mathrm{O}, \mathrm{CH}_{4}$ and $\mathrm{CO}_{2}$ beneath Lolium perenne under elevated $\mathrm{CO}_{2}$ : the Swiss free air carbon dioxide enrichment experiment, Plant Soil, 198, 89-95, doi:10.1023/A:1004298309606, 1998.

IPCC: Greenhouse Gas Inventory: Reference Manual - revised 1996, IPCC Guidelines for National Greenhouse Gas Inventories, IGES, Japan, available at: http://www.ipcc-nggip.iges.or.jp/ public/gl/invs1.html (last access: 13 March 2013), 1997.

IPCC: Good Practice Guidance and Uncertainty Management in National Greenhouse Gas Inventories (IPCC GPG), Institute for Global Environmental Strategies (IGES), Japan, available at: http://www.ipcc-nggip.iges.or.jp/public/gp/english/ (last access: 13 March 2013), 2000.

IPCC: Good Practice Guidance for Land Use, Land-Use Change and Forestry (IPCC GPG LULUCF), edited by: Penman, J., Gytarsky, M., Hiraishi, T., Krug, T., Kruger, D., Pipatti, R., Buendia, L., Miwa, K., Ngara, T., Tanabe, K., and Wagner, F., Institute for Global Environmental Strategies (IGES), Japan, available at: http://www.ipcc-nggip.iges.or.jp/public/gpglulucf/gpglulucf. html (last access: 15 March 2013), 2003.

IPCC: 2006 IPCC Guidelines for National Greenhouse Gas Inventories, Institute for Global Environmental Strategies (IGES), Japan, available at: http://www.ipcc-nggip.iges.or.jp/ public/2006gl/index.html (last access: 13 March 2013), 2006.

Janssens-Maenhout, G., Dentener, F., Van Aardenne, J., Monni, S., Pagliari, V., Orlandini, L., Klimont, Z., Kurokawa, J., Akimoto, H., Ohara, T., Wankmueller, R., Battye, B., Grano, D., Zuber, A., and Keating, T.: EDGAR-HTAP: a harmonized grid- 
ded air pollution emission dataset based on national inventories, European Commission Publications Office, Ispra (Italy), 41 pp., 2012.

Jensen, B.: Methanogenesis in monogastric animals, Environ. Monit. Assess., 42, 99-112, doi:10.1007/BF00394044, 1996.

Kammann, C., Grünhage, L., Jäger, H.-J., and Wachinger, G.: Methane fluxes from differentially managed grassland study plots: the important role of $\mathrm{CH}_{4}$ oxidation in grassland with a high potential for $\mathrm{CH}_{4}$ production, Environ. Poll., 115, 261273, doi:10.1016/S0269-7491(01)00103-8, 2001.

Kemenes, A., Forsberg, B. R., and Melack, J. M.: Methane release below a tropical hydroelectric dam, Geophys. Res. Lett., 34, doi:10.1029/2007GL029479, 2007.

King, J. Y., Reeburgh, W. S., and Regli, S. K.: Methane emission and transport by arctic sedges in Alaska: results of a vegetation removal experiment, J. Geophys. Res.-Atmos., 103, 2908329092, 1998.

Kinsman, R., Sauer, F. D., Jackson, H. A., and Wolynetz, M. S.: Methane and carbon dioxide emissions from dairy cows in full lactation monitored over a six-month period, J. Dairy Sci., 78, 2760-2766, doi:10.3168/jds.S0022-0302(95)76907-7, 1995.

Klevenhusen, F., Kreuzer, M., and Soliva, C. R.: Enteric and manure-derived methane and nitrogen emissions as well as metabolic energy losses in cows fed balanced diets based on maize, barley or grass hay, Animal, 5, 450-461, 2010.

Klusman, R. W. and Dick, C. J.: Seasonal variability in $\mathrm{CH}_{4}$ emissions from a landfill in a cool, semiarid climate., J. Air Waste Manage.1995, 1632-1636, 2000.

Külling, D. R., Menzi, H., Krober, T. F., Neftel, A., Sutter, F., Lischer, P., and Kreuzer, M.: Emissions of ammonia, nitrous oxide and methane from different types of dairy manure during storage as affected by dietary protein content, J. Agr. Sci., 137, 235-250, 2001.

Külling, D. R., Dohme, F., Menz, H., Sutter, F., Lischer, P., and Kreuzer, M.: Methane emissions of differently fed dairy cows and corresponding methane and nitrogen emissions from their manure during storage, Environ. Monit. Assess., 79, 129-150, 2002.

Külling, D. R., Menzi, H., Sutter, F., Lischer, P., and Kreuzer, M.: Ammonia, nitrous oxide and methane emissions from differently stored dairy manure derived from grass- and hay-based rations, Nutr. Cycl. Agroecosys., 65, 13-22, doi:10.1023/A:1021857122265, 2003.

Kupper, T., Bonjour, C., Achermann, B., Zaucker, F., Rihm, B., Nyfeler-Brunner, A., Leuenberger, C., and Menzi, H.: Ammoniakemissionen in der Schweiz: Neuberechnung 1990-2007 Prognose bis 2020, available at: http://www.bafu.admin.ch/luft/ 11017/11023/11205/index.html (last access: 15 March 2013), 79 pp., 2010

Levin, I., Glatzel-Mattheier, H., Marik, T., Cuntz, M., Schmidt, M., and Worthy, D. E.: Verification of German methane emission inventories and their recent changes based on atmospheric observations, J. Geophys. Res., 104, 3447-3456, doi:10.1029/1998JD100064, 1999.

Liebner, S., Schwarzenbach, S., and Zeyer, J.: Methane emissions from an alpine fen in central Switzerland, Biogeochemistry, 109, 287-299, doi:10.1007/s10533-011-9629-4, 2012.
Lin, J. C., and Gerbig, C.: Accounting for the effect of transport errors on tracer inversions, Geophys. Res. Lett., 32, L01802, doi:10.1029/2004GL021127, 2005.

Lowry, D., Holmes, C. W., Rata, N. D., O'Brien, P., and Nisbet, E. G.: London methane emissions: use of diurnal changes in concentration and $\delta^{13} \mathrm{C}$ to identify urban sources and verify inventories, J. Geophys. Res., 106, 7427-7448, doi:10.1029/2000JD900601, 2001.

Mahrt, L., and Sun, J.: Dependence of exchange coefficients on averaging scale or grid size. Quart. J. Roy. Met. Soc., 121 (528), 1835-1852, 1995.

Manning, A. J., O’Doherty, S., Jones, A. R., Simmonds, P. G., and Derwent, R. G.: Estimating UK methane and nitrous oxide emissions from 1990 to 2007 using an inversion modeling approach, J. Geophys. Res., 116, D02305, doi:10.1029/2010JD014763, 2011.

Merbold, L., Steinlin, C., and Hagedorn, F.: Winter greenhouse gas fluxes $\left(\mathrm{CO}_{2}, \mathrm{CH}_{4}\right.$ and $\left.\mathrm{N}_{2} \mathrm{O}\right)$ from a subalpine grassland, Biogeosciences, 10, 3185-3203, doi:10.5194/bg-10-3185-2013, 2013.

Miller, J. B.: The carbon isotopic composition of atmospheric methane and its constraint on the global methane budget, in: Stable Isotopes and Biosphere-Atmosphere Interactions, edited by: Flanagan, L. B., Ehleringer, J. R., and Pataki, D. E., Academic Press, San Diego, 288-310, 2005.

Moore, T. R. and Roulet, N. T.: Methane flux-water-table relations in northern wetlands, Geophys. Res. Lett., 20, 587-590, 1993.

Mosier, A., Schimel, D., Valentine, D., Bronson, K., and Parton, W.: Methane and nitrous oxide fluxes in native, fertilized and cultivated grasslands, Nature, 350, 330-332, doi:10.1038/350330a0, 1991.

Münger, A. and Kreuzer, M.: Methane emission as determined in contrasting dairy cattle breeds over the reproduction cycle, Int. Congr. Ser., 1293, 119-122, doi:10.1016/j.ics.2006.01.072, 2006.

Nauer, P. A., Dam, B., Liesack, W., Zeyer, J., and Schroth, M. H.: Activity and diversity of methane-oxidizing bacteria in glacier forefields on siliceous and calcareous bedrock, Biogeosciences, 9, 2259-2274, doi:10.5194/bg-9-2259-2012, 2012.

Park, S., Brown, K. W., Thomas, J. C., Lee, I., and Sung, K.: Comparison study of methane emissions from landfills with different landfill covers, Environ. Earth Sci., 60, 933-941, doi:10.1007/s12665-009-0229-8, 2010.

Polson, D., Fowler, D., Nemitz, E., Skiba, U., McDonald, A., Famulari, D., Marco, C. Di, Simmons, I., Weston, K., Purvis, R., Coe, H., Manning, A. J., Webster, H., Harrison, M., O'Sullivan, D., Reeves, C., and Oram, D.: Estimation of spatial apportionment of greenhouse gas emissions for the UK using boundary layer measurements and inverse modelling technique, Atmos. Environ., 45, 1042-1049, doi:10.1016/j.atmosenv.2010.10.011, 2011.

Pouliot, G., Pierce, T., Van der Gon, H. D., Schaap, M., Moran, M., and Nopmongcol, U.: Comparing emission inventories and model-ready emission datasets between Europe and North America for the AQMEII project, Atmos. Environ., 53, 4-14, doi:10.1016/j.atmosenv.2011.12.041, 2012.

SAEFL: Luftschadstoff-Emissionen aus natürlichen Quellen in der Schweiz, in Schriftenreihe Umwelt-Luft, vol. 257, Swiss Agency for the Environment, Forests and Landscape (SAEFL), 1996. 
Schroth, M. H., Eugster, W., Gómez, K. E., Gonzalez-Gil, G., Niklaus, P. A., and Oester, P.: Above- and below-ground methane fluxes and methanotrophic activity in a landfill-cover soil, Waste Manage., 32, 879-889, doi:10.1016/j.wasman.2011.11.003, 2012.

Schubert, C. J., Lucas, F. S., Durisch-Kaiser, E., Stierli, R., Diem, T., Scheidegger, O., Vazquez, F., and Müller, B.: Oxidation and emission of methane in a monomictic lake (Rotsee, Switzerland), Aquat. Sci., 72, 455-466, doi:10.1007/s00027010-0148-5, 2010.

Schubert, C. J., Diem, T., and Eugster, W.: Methane emissions from a small wind shielded lake determined by eddy covariance, flux chambers, anchored funnels, and boundary model calculations: a comparison, Environ. Sci. Technol., 46, 4515-4522, doi:10.1021/es203465x, 2012.

SFOE: Erläuternder Bericht zur Energiestrategie 2050, Swiss Federal Office of Energy SFOE, available at: $\quad$ http://www.admin.ch/ch/d/gg/pc/documents/2210/ Energiestrategie-2050_Erl-Bericht_de.pdf (last access: 18 April 2013), 138 pp., 2012a.

SFOE: Schweizerische Gesamtenergiestatistik 2011, Swiss Federal Office of Energy SFOE, available at: http://www.bfe.admin.ch/themen/00526/00541/00542/00631/ index.html?lang=de\&dossier_id=00763 (last access: 13 March 2013), 61 pp., 2012b.

SGWA: Technische Jahresstatistik Gas 2011, Swiss Gas and Water Industry Association (SGWA), available at: http://www.svgw.ch/ index.php?id=272\&L=0 (last access: 30 June 2013), 2012.

Smith, K. A., Dobbie, K. E., Ball, B. C., Bakken, L. R., Sitaula, B. K., Hansen, S., Brumme, R., Borken, W., Christensen, S., Priemé, A., Fowler, D., Macdonald, J. A., Skiba, U., Klemedtsson, L., Kasimir-Klemedtsson, A., Degórska, A., and Orlanski, P.: Oxidation of atmospheric methane in Northern European soils, comparison with other ecosystems, and uncertainties in the global terrestrial sink, Glob. Change Biol., 6, 791-803, doi:10.1046/j.1365-2486.2000.00356.x, 2000.

Soliva, C. R.: Report to the attention of IPCC about the data set and calculation method used to estimate methane formation from enteric fermentation of agricultural livestock population and manure management in Swiss agriculture, available at: http://www.bafu.admin.ch/climatereporting/00545/ 01913/index.html (last access: 15 March 2013), 2006.

Staerfl, S. M., Zeitz, J. O., Kreuzer, M., and Soliva, C. R.: Methane conversion rate of bulls fattened on grass or maize silage as compared with the IPCC default values, and the longterm methane mitigation efficiency of adding acacia tannin, garlic, maca and lupine, Agr. Ecosyst. Environ., 148, 111-120, doi:10.1016/j.agee.2011.11.003, 2012.

Stiehl-Braun, P. A., Powlson, D. S., Poulton, P. R., and Niklaus, P. A.: Effects of $\mathrm{N}$ fertilizers and liming on the microscale distribution of soil methane assimilation in the long-term Park Grass experiment at Rothamsted, Soil Biol. Biochem., 43, 1034-1041, doi:10.1016/j.soilbio.2011.01.020, 2011.
Swisstopo: VECTOR25: Das digitale Landschaftsmodell der Schweiz, Federal Office of Topography (swisstopo), 2004.

Ugolini, F., Gómez, K., Schroth, M. H., Eugster, W., Niklaus, P., Oester, P., and Zeyer, J.: Seasonal changes in the fate of methane in a landfill-cover soil, in: Annual Meeting of the Swiss Society for Microbiology, June 4-5, Lausanne, Switzerland, 2009.

Van den Pol-van Dasselaar, A., Van Beusichem, M. L., and Oenema, O.: Effects of nitrogen input and grazing on methane fluxes of extensively and intensively managed grasslands in the Netherlands, Biol. Fert. Soils, 29, 24-30, doi:10.1007/s003740050520, 1999.

Vermeulen, A. T., Eisma, R., Hensen, A., and Slanina, J.: Transport model calculations of NW-European methane emissions, Environ. Sci. Policy, 2, 315-324, doi:10.1016/S1462-9011(99)00021$0,1999$.

VSG: Erdgas in der Schweiz - VSG-Jahresstatistik, Verband der Schweizerischen Gasindustrie (VSG), available at: http://www.erdgas.ch/fileadmin/customer/erdgasch/Data/

Broschueren/Jahresstatistik/VSG-Jahresstatistik_2012.pdf (last access: 15 March 2013), 26 pp., 2012.

Wennberg, P. O., Mui, W., Wunch, D., Kort, E. A., Blake, D. R., Atlas, E. L., Santoni, G. W., Wofsy, S. C., Diskin, G. S., Jeong, S., and Fischer, M. L.: On the sources of methane to the Los Angeles atmosphere, Environ. Sci. Technol., 46, 9282-9289, doi:10.1021/es301138y, 2012.

Whalen, S. C., Reeburgh, W. S., and Sandbeck, K. A.: Rapid methane oxidation in a landfill cover soil, Appl. Environ. Microb., 56, 3405-3411, 1990.

Wratt, D. S., Gimson, N. R., Brailsford, G. W., Lassey, K. R., Bromley, A. M., and Bell, M. J.: Estimating regional methane emissions from agriculture using aircraft measurements of concentration profiles, Atmos. Environ., 35, 497-508, 2001.

Wunderlin, P., Mohn, J., Joss, A., Emmenegger, L., and Siegrist, H.: Lachgas $\left(\mathrm{N}_{2} \mathrm{O}\right)$ Emissionen aus Abwasserreinigungsanlagen (ARA), Aqua \& Gas, 2, 54-59, 2013.

Xinmin, J.: Die Methanemissionen der Schweizer Gasindustrie, Gas, Wasser, Abwasser, 5, 337-345, 2004.

Zeitz, J. O., Soliva, C. R., and Kreuzer, M.: Swiss diet types for cattle: how accurately are they reflected by the Intergovernmental Panel on Climate Change default values?, J. Integr. Environ. Sci., 9, 199-216, doi:10.1080/1943815X.2012.709253, 2012.

Zellweger-Fischer, J.: Schweizer Feldhasenmonitoring 2012/Suivi des populations de lièvres en Suisse en 2012, Schweizerische Vogelwarte Sempach, 28 pp., 2012.

Zhao, S., and Liu, S.: Scale criticality in estimating ecosystem carbon dynamics, Glob. Change Biol., doi:10.1111/gcb.12496, 2013.

Zhu, X., Zhuang, Y., Lu, X., and Song, L.: Spatial scale-dependent land-atmospheric methane exchange in the northern high latitudes from 1993 to 2004, Biogeosciences Discuss., 10, 1845518478, doi:10.5194/bgd-10-18455-2013, 2013. 